\title{
DATING THE LASCAUX CAVE GOUR FORMATION
}

\author{
$\mathrm{D} \mathrm{Genty}^{1} \bullet \mathrm{S} \mathrm{Konik}^{2} \bullet \mathrm{H}_{\text {Valladas }}^{3} \cdot \mathrm{D} \mathrm{Blamart}^{3} \cdot \mathrm{J} \mathrm{Hellstrom}^{4} \bullet \mathrm{M} \mathrm{Touma}^{1} \bullet \mathrm{C}_{\text {Moreau }}^{5} \bullet$

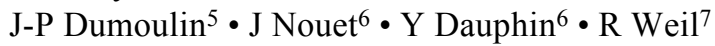

\begin{abstract}
Lascaux Cave is renowned for its outstanding prehistoric paintings, strikingly well-preserved over about $18,000 \mathrm{yr}$. While stalagmites and stalactites are almost absent in the cave, there is an extensive calcite flowstone that covered a large part of the cave until its opening for tourists during the 1950s. The deposit comprises a succession of calcite rims, or "gours," which allowed seepage water to pond in large areas in the cave. Their possible role in preservation of the cave paintings has often been evoked, but until now this deposit has not been studied in detail. Here, we present 24 new radiocarbon accelerator mass spectrometry (AMS) and 6 uranium-thorium (U-Th) analyses from the calcite of the gours, 4 AMS ${ }^{14} \mathrm{C}$ dates from charcoals trapped in the calcite, and $4 \mathrm{AMS}{ }^{14} \mathrm{C}$ analyses on organic matter extracted from the calcite. Combining the calibrated ${ }^{14} \mathrm{C}$ ages obtained on charcoals and organic matter and U-Th ages from ${ }^{14} \mathrm{C}$ analyses made on the carbonate, has allowed the calculation of the dead carbon proportion (dcp) of the carbonate deposits. The latter, used with the initial atmospheric ${ }^{14} \mathrm{C}$ activities reconstructed with the new IntCal09 calibration data, allows high-resolution age estimation of the gour calcite samples and their growth rates. The carbonate deposit grew between 9530 and $6635 \mathrm{yr}$ cal BP (for dcp $=10.7 \pm 1.8 \%$; $2 \sigma$ ) or between 8518 and $5489 \mathrm{yr}$ cal BP (for dcp $=20.5 \pm 1.9 \% ; 2 \sigma$ ). This coincides with humid periods that can be related to the Atlantic period in Europe and to Sapropel 1 in the eastern Mediterranean Sea. However, geomorphological changes at the cave entrance might also have played a role in the gour development. In the 1940s, when humans entered the cave for the first time since its prehistoric occupation, the calcite gours had already been inactive for several thousand years.
\end{abstract}

\section{INTRODUCTION}

Since its discovery in September 1940, Lascaux Cave has remained one of the most famous painted caves worldwide. The several hundred prehistoric paintings, drawings, and engravings of horses, aurochs, bisons, stags, ibex, muffles, and rhinoceros, together with enigmatic signs and an illustration of a human, is among the richest collections of Paleolithic art in the word (Leroi-Gourhan and Allain 1979; Aujoulat 2004). However, the millions of visitors that entered Lascaux Cave to admire these figures during the 15 years following its official opening in September 1948 brought in microbes, humidity, heat, and $\mathrm{CO}_{2}$. These impacts, combined with the effects of light and air conditioning, caused damage due to vegetal and microbial activity, and mineral precipitation that led to the definitive closing of the cave in April 1963 (Delluc and Delluc 2008). During the early 1960s, a new air conditioning system was developed by Paul-Marie Guyon to recreate a stable environment in the cave and avoid seasonal condensation in the galleries: a cold point was created at the cave entrance, $\mathrm{CO}_{2}$ excess was evacuated, and isothermal doors were installed (Guyon 1980). This system worked well until 2000 when the administration decided to change it. Since then, a mushroom, Fusariul solani, invaded the cave and, associated with bacteria (i.e. Pseudomonas fluorescen) and arthropods, provoked a new disequilibrium in the cave (Bastian et al. 2007, 2009, 2010; Bastian and Alabouvette 2009). The origin of this recent contamination is still debated and hypotheses involving subtle climatic changes inside the cave during the last years have been raised (Lacanette et al. 2009).

Key to solving this complex contamination problem will be an understanding of how the cave environment has varied before its discovery, in terms of humidity, $\mathrm{pCO}_{2}$, temperature, and ventilation.

${ }^{1}$ LSCE, UMR CEA/CNRS/UVSQ 8212, L'Orme des Merisiers CEA Saclay, 91191 Gif sur Yvette Cedex, France. Corresponding author. Email: dominique.genty@1sce.ipsl.fr.

${ }^{2}$ Centre National de Préhistoire, 38 rue du 26e Régiment d'Infanterie, 24000 Périgueux, France. Also: PACEA UMR 5199 CNRS, France.

${ }^{3}$ LSCE, UMR CEA/CNRS/UVSQ 8212, Avenue de la Terrasse, 91191 Gif sur Yvette Cedex, France.

${ }^{4}$ School of Earth Sciences, University of Melbourne, VIC 3010, Australia.

${ }^{5}$ Laboratoire de Mesure du Carbone 14, UMS 2572 bâtiment 450 porte 4, CEA Saclay, 91191 Gif sur Yvette Cedex, France.

${ }^{6}$ IDES, UMR 8148, Université de Paris XI, 91405 Orsay Cedex, France.

${ }^{7}$ LPS, UMR 8502, Université de Paris XI, 91405 Orsay, France. 
Notably, since the paintings were made at about 18-21 kyr cal BP, Lascaux Cave has experienced large climatic changes such as the last deglaciation $\left(\sim 10-15^{\circ} \mathrm{C}\right)$, the abrupt Younger Dryas onset $(5-$ $10{ }^{\circ} \mathrm{C}$ in a few years), and all of their consequences in terms of hydrology and vegetation changes above the cave (Renssen et al. 2001; Magny and Bégeot 2004; Frisia et al. 2005; Genty et al. 2006; Fletcher et al. 2010). The past temperatures inside Lascaux Cave are likely to have varied greatly during these periods, mainly because the cave is shallow (7-10 $\mathrm{m}$ subsurface for the Salle des Taureaux and Passage rooms; Glory et al. 2008) and relatively short; distances of the main rooms from the entrance are $<70 \mathrm{~m}$. Also, the thermal wave likely took a few months to a few years to reach the inside of the cave, which is short compared to climatic changes (Taine et al. 2003; Luetscher and Jeannin 2004). The evolution of the hydrology in Lascaux Cave is more difficult to constrain due to an impermeable layer of Santonian marl covering the cave and preventing seepage into the cave except at the entrance where this layer is pierced. The entrance hole allowed the water, draining from the impermeable Santonian layer, to enter the cave, forming a long carbonate deposit consisting of flowstone and dams called "gours" that developed in the Salle des Taureaux and in the Passage (Figures 1 and 2). However, the entrance morphology has changed considerably since the Last Glacial period (Glory et al. 2008), and the water flow to the cave was consequently constrained by these changes too, in parallel with the climatic variations. There are no other significant speleothems (stalactites, stalagmites) that could be used to reconstruct past hydrology in Lascaux Cave.

In order to better constrain the possible effect on preservation of the paintings of the water flowing inside Lascaux Cave, and to have a first idea of the gour age, it is important to know if gours were still active before the artificial modifications. Photos of the first days, before any extension of the cave entrance or installations inside the cave were made, are rare, but they show no water in the gours (i.e. Leroi-Gourhan and Allain 1979:52, 56; unpublished photo of the Salle des Taureaux gours from 1940, Th Felix collection, Figure 1). Early testimonies of the first explorers of the cave, during the autumn of 1940, are contradictory. On one hand, H Breuil wrote that, in order to take pictures in the Salle des Taureaux, he was obliged to pierce the gour to evacuate water that had filled them during the autumn (in Delluc and Delluc 2003:169). On the other hand, several hints suggest that the gours were not active: in their description of their discovery, the young boys that first entered the cave, in September 1940, said that they had to "stride over" the gours but do not mention any water in the cave (in Delluc and Delluc 2003, J Marsal testimony, p 304). Moreover, the detailed description made by $\mathrm{M}$ Thaon, a young speleologist that worked for $\mathrm{H}$ Breuil, evokes "amorphous calcite" when speaking about the gours and even suggests that they stopped growing a long time previously (in Delluc and Delluc 2003:294).

Despite its renown, very few age determinations have been made on Lascaux Cave remains (Table 1). The archaeological layer, located below the flowstone calcite deposit, was dated using ${ }^{14} \mathrm{C}$ analyses (Table 1) from 2 charcoals samples, 1 reindeer antler, and 1 assegai bone. Ages range between 23,360 and 16,920 yr cal BP (Glory 1964; Leroi-Gourhan and Allain 1979; Valladas et al., unpublished results). The age (10,690-7180 yr cal BP) of the calcite flowstone and gours that occupied the soil of the Salle des Taureaux and of the Passage was estimated using only 5 measurements from charcoals found just below its base and above its surface (Glory 1964; Leroi-Gourhan and Allain 1979; Table 1). Until now, the carbonate deposit has not been studied and its age and duration is not known.

Here, we present new age determinations from this deposit from various materials using ${ }^{14} \mathrm{C}$ accelerator mass spectrometry (AMS): carbonate, charcoal particles found trapped in the gours, and organic matter extracted from this calcite. Additional analyses on the carbonate were made by uranium-thorium (U-Th) MC-ICP-MS, which gave much less precise results, but nonetheless provide confirmation of the former ${ }^{14} \mathrm{C}$ ages. A cross-section of one of the gours was extensively studied, allowing us to constrain the time duration of its construction. 


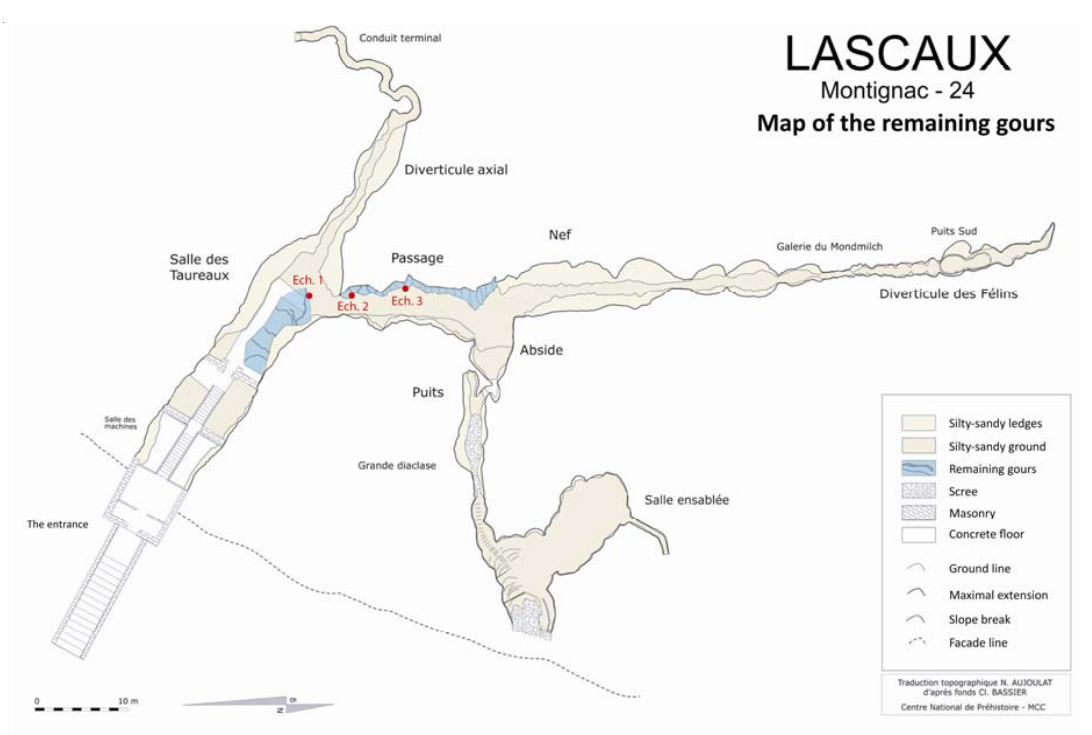

a)

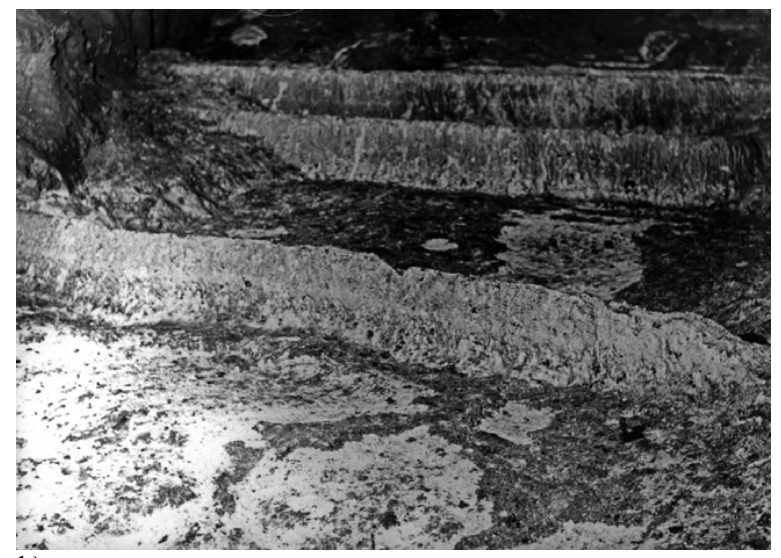

b)

Figure 1 a) Topographical map of Lascaux Cave and location of gour sampling; b) one of the first photographs of the gour in the Salle des Taureaux (unknown photographer, (T) Felix collection). Note that the gours are dry and have some signs of damage in some places.

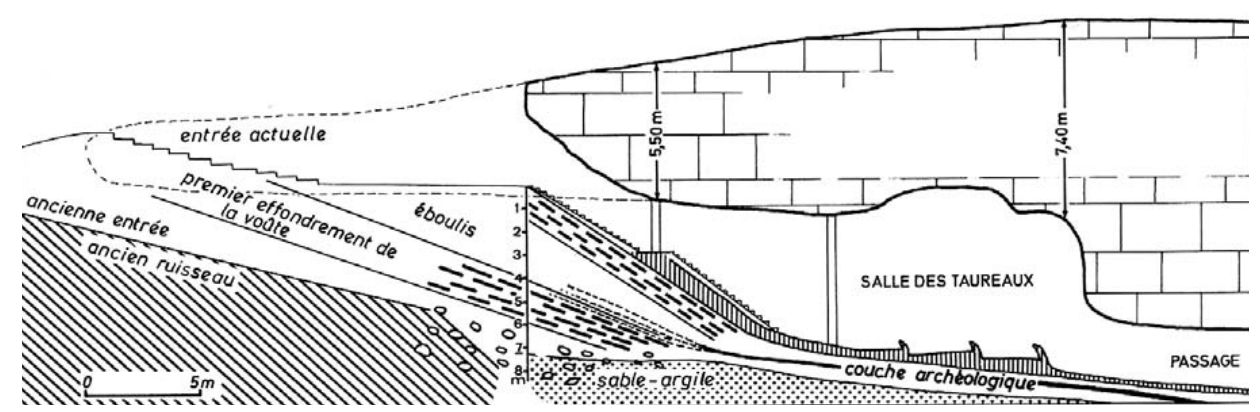

Figure 2 Schematic vertical cross-section of the Lascaux Cave entrance from the Entrance to the Passage chamber (Glory et al. 2008). 


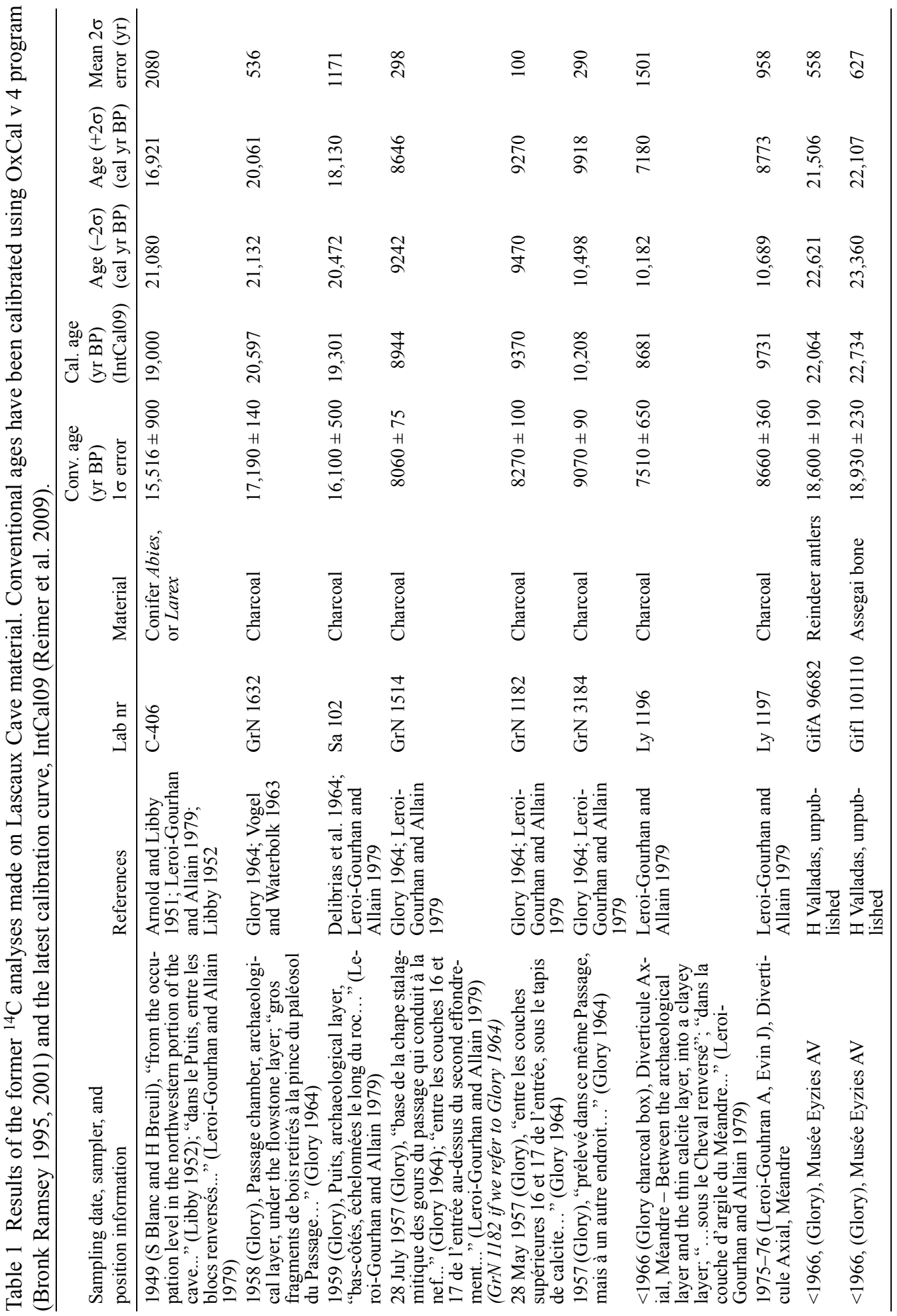




\section{SITE SETTINGS AND SAMPLE DESCRIPTIONS}

\section{Site Settings}

Lascaux Cave $\left(45^{\circ} 03^{\prime} \mathrm{N} ; 1^{\circ} 10^{\prime} \mathrm{E} ; 185 \mathrm{~m}\right.$ asl) developed in Coniacian sandy limestone at the top of a hill situated just above the town of Montignac, SW France. Its total length is $250 \mathrm{~m}$ and the average height of the cave is $4 \mathrm{~m}$; the galleries that can be explored are only a small part of a much larger and deeper karstic network (Vouvé 1979). It is a shallow cave above which the Santonian limestone layer thickness does not exceed $18 \mathrm{~m}$. The base of the Santonian formation consists of a 5-cm-thick clayey layer that considerably reduces water seepage inside the cave and which drains the flow of the upper aquifer towards the entrance; this flow explains the formation of the flowstone and gours found inside the cave, mainly in the Salle des Taureaux and the Passage chambers (Figures 1 and 2).

The complex cave entrance history was reconstructed by studying the 18 layers found in the collapse zone at the entrance (Figure 2; Glory et al. 2008). The archaeological layer is found here just above a layer of large limestone blocks that fell from the cave ceiling for unknown reasons. The length of the Coniacian blocks is up to $2.5 \mathrm{~m}$ and the thickness of the layer is $2 \mathrm{~m}$, which documents the importance of this event (see the entrance cross-section, Glory et al. 2008:33). Human artifacts (flint tools, animal bones, lamps, etc.) were found in the following layer, $0.5-0.7 \mathrm{~m}$ thick, constituting the archaeological layer. At that time, the entrance was of $\sim 2 \mathrm{~m}$ height. The archaeological layer is covered by a 1.5-m-thick layer of clay, limestone gravels, and scallops attributed to a cold period. Just above this, a second significant collapse occurred and left a 2-m-thick layer of large limestone blocks (Leroi-Gourhan and Allain 1979; Glory et al. 2008). This last event is likely to have allowed water, directed by the impermeable Santonian layer that covers the cave, to enter and form a travertine in which oak and walnut tree leaves were fossilized (Leroi-Gourhan and Allain 1979; Glory et al. 2008). Deeper inside the cave, the water flow deposited flowstone and gours directly above the archaeological layer. Subsequently, the growing carbonate layer and soil development again closed the cave entrance. Ranging from a typical travertine with vegetal remains at the cave entrance to a flowstone and gour formation with no visible imprints, the petrography of this carbonate layer is not typical of speleothems, as described below.

\section{Sampling and Petrographical Description}

Deposits of the entrance were extracted during the opening of the cave, and unfortunately there are now no remains that can be studied there. However, inside the cave the carbonate layer is still in place over large areas. We have sampled pieces of the flowstone formation at 3 different locations (Figure 1):

Location 1: gour-A is a piece $(15 \times 10 \times 5 \mathrm{~cm})$ from the Salle des Taureaux, at the base of the thick flowstone underlying a gour close to the Passage entrance; just at the contact with the clayey layer found below.

Location 2: gour-B was sampled at the entrance of the Passage, on the left side when going towards the Nef, where flowstone covers the archaeological layer; 4 pieces $(4-10 \times 3 \times 4 \mathrm{~cm})$ were sampled in order to give a vertical profile from the contact with the archaeological layer to the top of the flowstone.

Location 3: gour-C comes from the middle of the Passage chamber, on the left side. It is a $20 \times 18 \times 5 \mathrm{~cm}$ section of a gour that covered the clayey layer. This sample consists of a cross-section taken from the border of a gour that was broken during the 1957-58 cave works, when a deep trench was made to accomodate large pipes for extraction of cave air (Delluc and Delluc 2003).

The flowstone/gour macroscopic fabrics are unusual for a speleothem as it is made of a white and powdery carbonate that feels light in one's hands. Diffraction X-ray analysis of a piece of gour-C shows that it is made of calcite (Figure 3). Its porosity, estimated by weighing a cube of carbonate 
of known volume, is $\sim 43 \%$, which is very high compared to most speleothems (i.e. $<10 \%$; Genty and Quinif 1996). Images from a scanning electron microscope were made on 3 different samples: the first from a gour that was left near the cave entrance after the work conducted in the 1950s (Figure $4 \mathrm{a}-\mathrm{c}$ ) and its exact provenance is unknown; the second and the third from gour-C that developed in the Passage. The first sample reveals a structure of intricate calcite needles about $200 \mu \mathrm{m}$ long and about 10 to $20 \mu \mathrm{m}$ wide where crystalline surfaces are visible (Figure $4 \mathrm{a}-\mathrm{c}$ ); this fabric is close to the dendrite fabric as defined by Frisia et al. (2000). Gour-C samples also show calcite needles: some appear thinner than those observed in the previous sample (i.e. 100-200 $\mu \mathrm{m}$ long and $\sim 2 \mu \mathrm{m}$ wide; Figure 4d,e), some others are slightly larger and are characterized by well-defined crystalline surfaces and a central vein (Figure 4f). This vein or furrow has been previously observed in Lascaux Cave mondmilch (Billy and Chalvignac 1976; Billy and Blanc 1977), but its explanation remains unknown. Organic structures are also visible in the form of mats (Figure 4d) and thin filaments of $\sim 0.1 \mu \mathrm{m}$ (Figure $4 \mathrm{f}, \mathrm{g}, \mathrm{h}$ ). The first descriptions of this material suggested a specific structure: as well as the "amorphous calcite" of M Thaon (see Introduction), Glory used the term "hydrocalcite" in his description of the gours (Glory et al. 2008), which is understood here as a calcite similar to that of travertine formations. The association of calcite needles and organic structures is similar to the assemblages found in mondmilch deposits (Borsato et al. 2000), except that this calcite deposit is hard, and not soft as the mondmilch. We also note that the Galerie du Mondmilch in Lascaux Cave, which is covered by a thick layer of mondmilch with a very similar structure (Genty, unpublished results; Berrouet 2009), is located in the continuation of the Passage and Nef galleries (Figure 1).

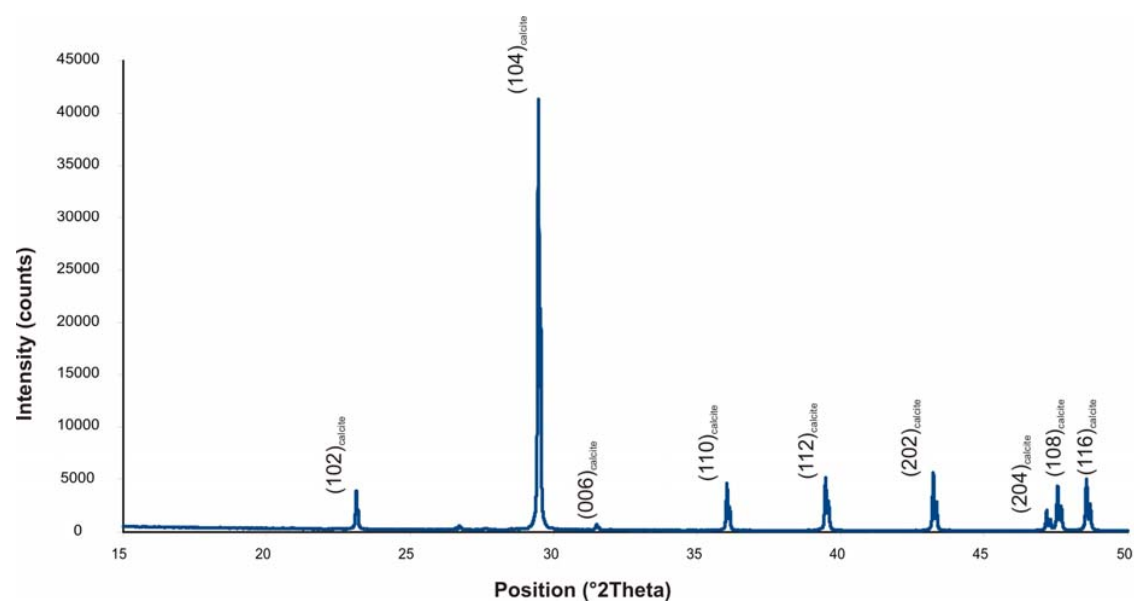

Figure $3 \mathrm{X}$ ray spectra of gour-C sample showing that it is made of calcite

Organic matter $(\mathrm{OM})$ residue has been extracted from 4 carbonates blocks from gour-C for ${ }^{14} \mathrm{C}$ dating (see Methods below). This OM, observed under an optical microscope, is composed of numerous brown filaments, a few $\mu \mathrm{m}$ large and several hundreds $\mu \mathrm{m}$ long (Figure 5), from still open provenance, but very similar to fungi or algae that are commonly found in tuff deposits (Casanova 1981).

Four charcoal pieces were found trapped inside the same gour-C sample (Figure 6). Their size is from 0.3 to $1 \mathrm{~cm}$ long and they are found at different levels of the gour from the base to the top. Two of them, observed under an optical microscope, revealed that they have come from deciduous trees (likely oak or beech); the other charcoals have a vitrified aspect that masks the trees' cell morphology. Gour-C is the most extensively studied sample because of its size, its continuous stratigraphy, and because of the presence of charcoals that were trapped in it. 

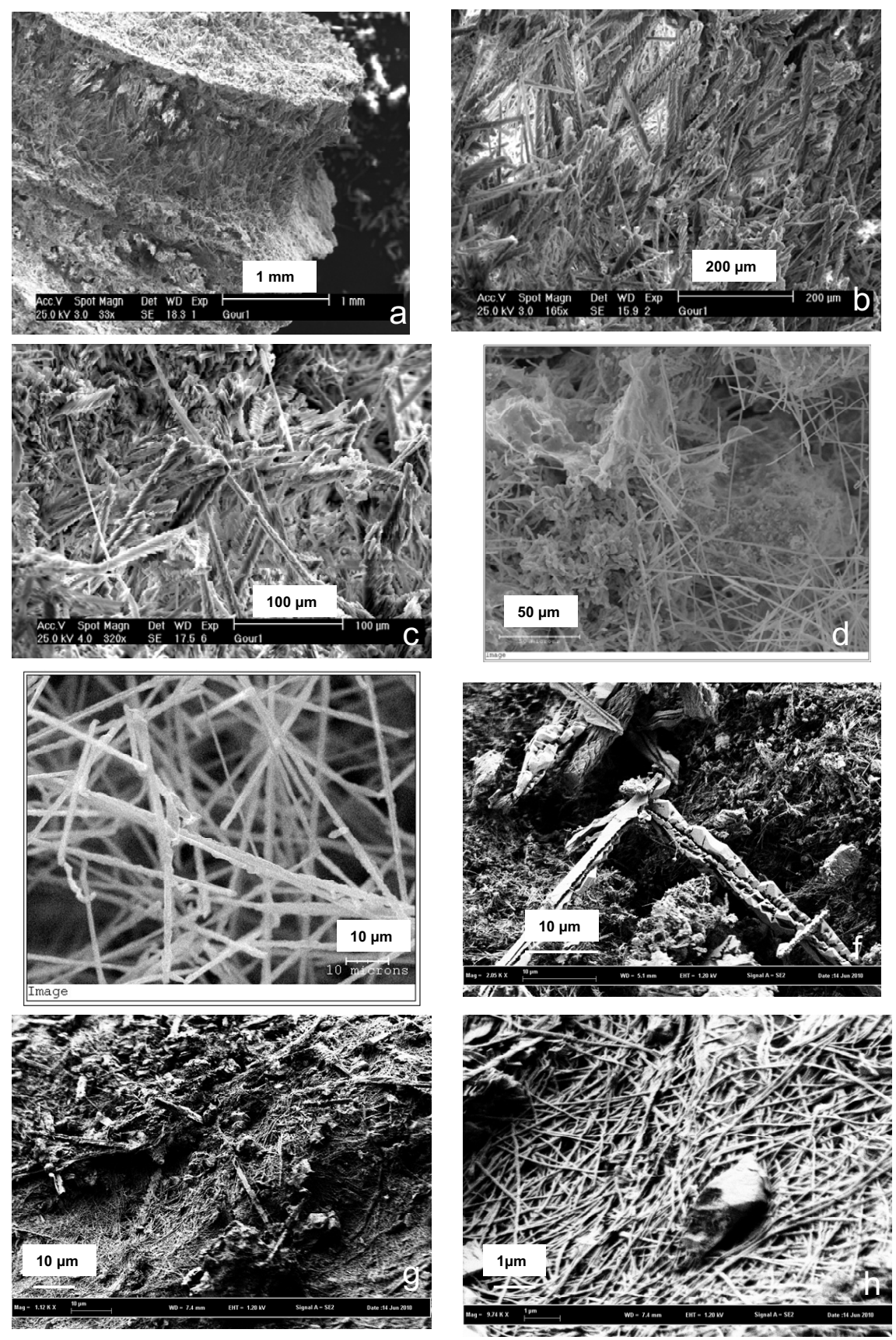

Figure 4 Scanning electron microscopic (SEM) images of 3 gour samples. The first sample (a,b,c) comes from an large gour piece from an unknown part of the cave; images were taken at the Paris-XI University, Geology Department in 1999 (Y Dauphin) on a Philips XL30 SEM; samples were gold gilded; the second sample is from gour-C (Passage chamber) (d,e); images were taken at the LSCE with carbon metallization (E Robin); the third sample also comes from gour-C; images f,g,h were taken at Paris-XI University, Laboratoire de Physique des Solides (R Weil) on a field emission scanning electron microscope without any metallization at low voltage. 

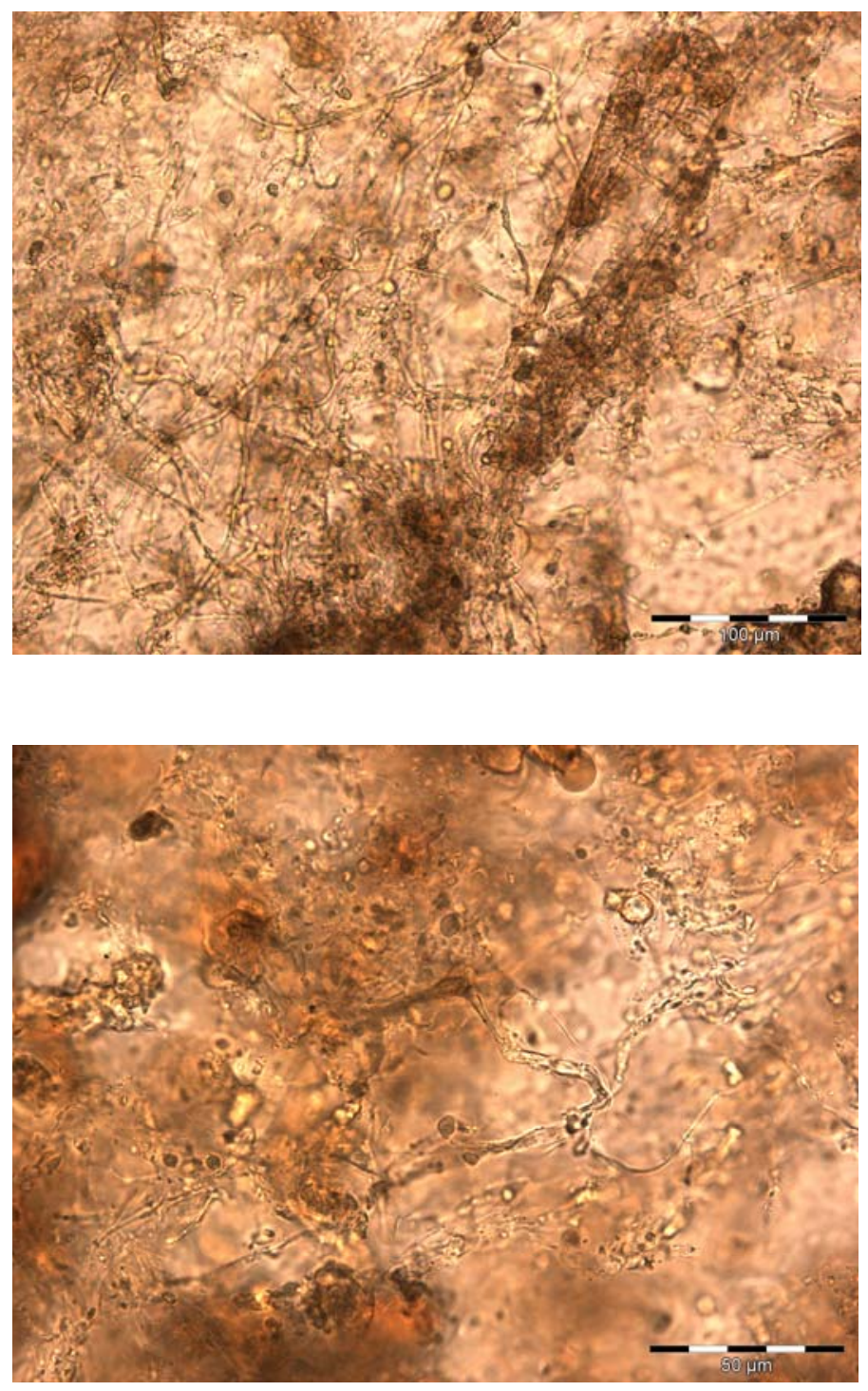

Figure 5 Organic matter residue extracted from the gour-C sample (optical microscope, natural light).

\section{METHODS}

We detail here the ${ }^{14} \mathrm{C}$ AMS methods used for the carbonate and charcoal samples and the dead carbon proportion (dep) calculation. U-Th dating of the gour calcite was by multicollector inductively coupled plasma mass spectrometry (MC-ICP-MS) at the University of Melbourne following the procedure of Hellstrom (2003). Small samples ( $20 \mathrm{mg}$ ) were used to allow targeting of relatively clean subdomains within the calcite, but even so the analyses were heavily contaminated with initial Th. An initial ${ }^{230} \mathrm{Th} /{ }^{232} \mathrm{Th}$ activity ratio of $0.65 \pm 0.2(2 \sigma)$ was estimated by stratigraphical constraint (Hellstrom 2006) and used to calculate corrected ages; its uncertainty dominates that of the calculated ages. 


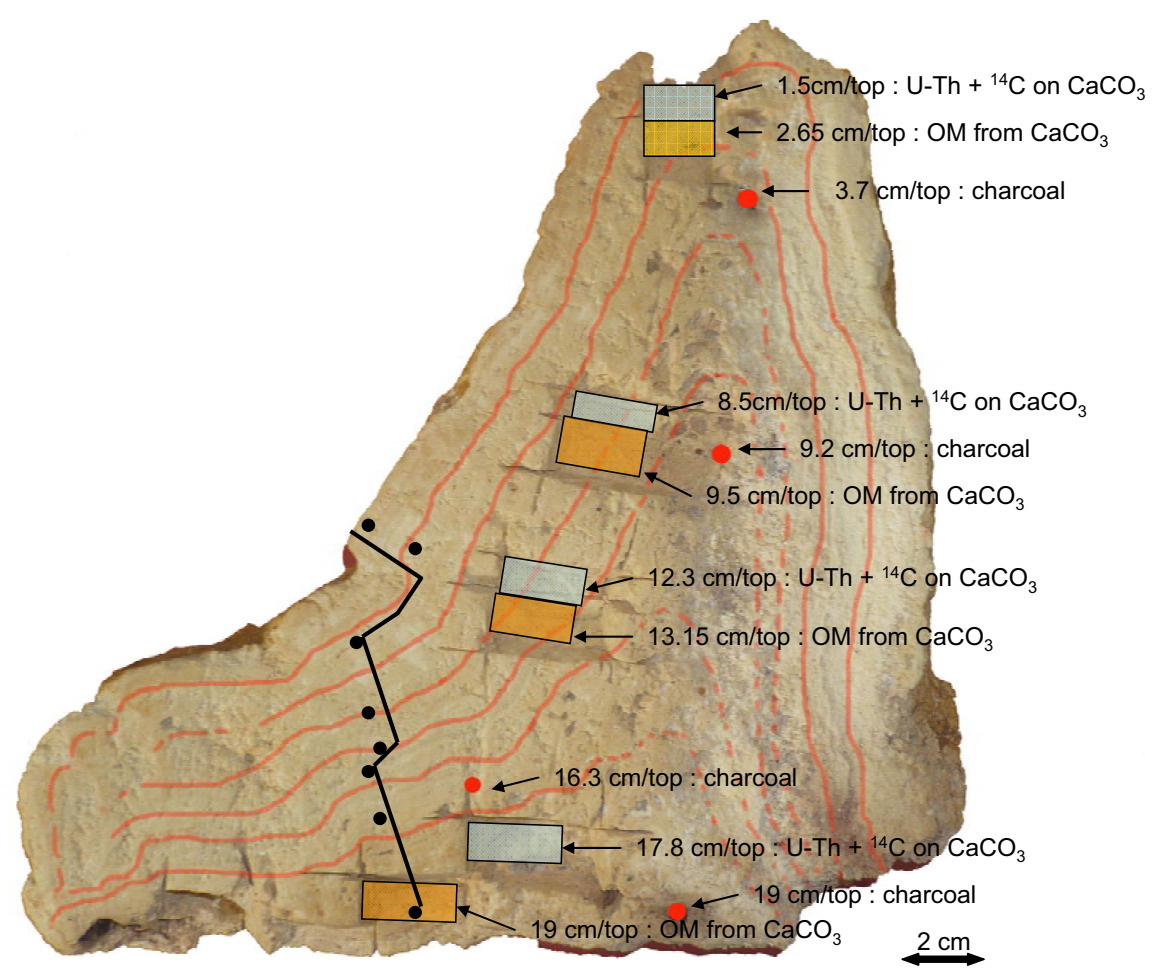

Figure 6 Vertical cross-section of gour-C with the position of analyzed samples: charcoals (red points); UTh and ${ }^{14} \mathrm{C}$ carbonate (blue boxes); extracted $\mathrm{OM}$ from carbonate blocks (orange boxes); carbonate ${ }^{14} \mathrm{C}$ on a lateral profile (black points). Red lines visualize the stratigraphy. Our first sampling covers the stratigraphy from base to top and was done to perform all type of analyses (large colored rectangles); later sampling for carbonate ${ }^{14} \mathrm{C}$ only and which needed much less material was done on a line perpendicular to the stratigraphy (black line). For interpretation of the references to color, the reader is referred to the online version of this article.

\section{Sample Preparation and AMS Analyses}

Carbonate samples were extracted using a 1-mm microdrill. Calcite powder samples for ${ }^{14} \mathrm{C}$ analysis were reacted with $\mathrm{H}_{3} \mathrm{PO}_{4}$ at $60{ }^{\circ} \mathrm{C}$ to obtain $\sim 1 \mathrm{mg}$ of $\mathrm{C}$ as $\mathrm{CO}_{2}$ gas. This is then graphitized on iron with hydrogen at $600^{\circ} \mathrm{C}$. Carbon atoms were counted by AMS (ARTEMIS; UMS 2572, Saclay).

The standard sample processing used to date the Lascaux charcoals involves a succession of acidbase-acid (ABA) treatments at $90{ }^{\circ} \mathrm{C}$ for $60 \mathrm{~min}$, which first dissolve the carbonates that may have come from the limestone or groundwater $(\mathrm{HCl} 0.5 \mathrm{~N})$, then the humic acids arising from the transformation of organic matter $(\mathrm{NaOH}, 0.1 \mathrm{~N})$. The "purified" charcoals are mixed with $\mathrm{CuO}$ and an $\mathrm{Ag}$ wire in a quartz tube, which is sealed under vacuum and heated at $835^{\circ} \mathrm{C}$ for $5 \mathrm{hr}$. The released $\mathrm{CO}_{2}$ is purified and trapped in a liquid nitrogen trap, quantified into a calibrated volume, and then collected in a glass vial. The $\mathrm{CO}_{2}$ is reduced to graphite. The iron and graphite powder is pressed into a 1-mm aluminium cathode for AMS measurement on ARTEMIS.

${ }^{14} \mathrm{C}$ activity is normalized to a $\delta^{13} \mathrm{C}$ of $-25 \%$. Conventional ${ }^{14} \mathrm{C}$ age calculations follow Mook and van der Plicht (1999). Uncertainties given take into account the statistics, results' variability, and blank error $(0.083 \pm 0.033 \mathrm{pMC})$. 
The organic matter $(\mathrm{OM})$ was extracted from the carbonate samples by acid attack (HCL at $10 \%$ over $24 \mathrm{hr}$ at $\sim 20{ }^{\circ} \mathrm{C}$ ), followed by a succession of 3 rinse/centrifugation cycles. For AMS preparation, the same process as for the charcoals was applied to the dried residue of OM.

\section{Age Calculations}

\section{Dead Carbon Proportion (dcp) Calculation}

The dead carbon proportion (dcp) of the carbonate deposit is found following Genty et al. (2001):

$$
\mathrm{dcp}=\left[1-\left(\mathrm{a}^{14} \mathrm{C}_{\text {init. }} / \mathrm{a}^{14} \mathrm{C}_{\text {atm.init. }}\right)\right] \times 100 \%
$$

where $\mathrm{a}^{14} \mathrm{C}_{\text {atm.init. }}$ is the atmospheric ${ }^{14} \mathrm{C}$ activity at the time of deposition and $\mathrm{a}^{14} \mathrm{C}_{\text {init. }}$ is the initial ${ }^{14} \mathrm{C}$ activity of the calcite defined by:

$$
\mathrm{a}^{14} \mathrm{C}_{\text {init. }}=\mathrm{a}^{14} \mathrm{C}_{\text {meas. }} /(\exp (-\ln (2) / 5730) \times t)
$$

with $t$ is the true age, which is found by one of the following: charcoal ${ }^{14} \mathrm{C}$ calibrated age, in $\mathrm{yr} / 2000$; ${ }^{230} \mathrm{Th} /{ }^{234} \mathrm{U}$ age, in $\mathrm{yr} / 2000$; extracted $\mathrm{OM}{ }^{14} \mathrm{C}$ calibrated age, in $\mathrm{yr} / 2000$; and where $\mathrm{a}^{14} \mathrm{C}_{\text {meas. }}$ is the measured calcite activity.

The $\mathrm{a}^{14} \mathrm{C}_{\mathrm{atm} \text {.init. }}$ value is found with the true age on the $\delta^{14} \mathrm{C}$ values given by the last calibration curve, IntCal09 (Reimer et al. 2009).

\section{${ }^{14} \mathrm{C}$ Age Calculations}

Charcoals and $\mathrm{OM}{ }^{14} \mathrm{C}$ ages are calculated with the OxCal v 4 program (Bronk Ramsey 1995, 2001), using the IntCal09 calibration curve (Reimer et al. 2009). Results are expressed in cal yr BP or yr/ 2000 (by adding $50 \mathrm{yr}$ ) in order to compare directly with the U-Th ages. Carbonate ${ }^{14} \mathrm{C}$ age is calculated using the same $\mathrm{OxCal}$ program with the carbonate ${ }^{14} \mathrm{C}$ activity $\left(\mathrm{a}^{14} \mathrm{C}_{\text {meas. }}\right)$, corrected by the dcp $\left(\mathrm{a}^{14} \mathrm{C}_{\text {corr. }}\right)$ :

$$
\mathrm{a}^{14} \mathrm{C}_{\text {corr. }}=\mathrm{a}^{14} \mathrm{C}_{\text {meas. }} /[(100-\mathrm{dcp}) / 100]
$$

where dcp is the dead carbon proportion (in \%), found as explained above.

The conventional ${ }^{14} \mathrm{C}$ age (yr BP) is then found by

$$
{ }^{14} \mathrm{C}_{\text {conv. }} \text { age }=-8033 \times \ln \left(\mathrm{a}^{14} \mathrm{C}_{\text {corr. }} / 100\right)
$$

Finally, the ${ }^{14} \mathrm{C}$ age is calibrated with the OxCal v 4 program.

For the carbonate age calculation, we used 2 different dcp: the dcp found with the charcoals and the dcp found with the extracted OM. By doing this, we assume the following: 1) that the charcoals and the OM material have the same age as the carbonate that trapped them, a hypothesis discussed above; and 2) that the dep did not change significantly during the gour development, which is a reasonable hypothesis as shown by the comparison of $\mathrm{U}-\mathrm{Th}$ and ${ }^{14} \mathrm{C}$ results on Holocene stalagmites (Genty et al. 1999).

The dep based on the U-Th measurements is very close to the one calculated by using the charcoals (Table 2), but we discarded it in the age calculations because its error is very large due to the large detrital thorium correction uncertainty of the U-Th ages. Consequently, we obtained 2 sets of ${ }^{14} \mathrm{C}$ ages on the carbonate samples of the Lascaux gours: one with the dcp based on charcoals, and another with the dep based on organic matter (OM). 
Table $2{ }^{14} \mathrm{C}$ results of the new organic samples from Lascaux Cave. Charcoals and OM samples have been extracted from the gour-C sample situated in the Passage. Conventional ages have been calibrated using the OxCal v 4 program (Bronk Ramsey 1995, 2001) and the IntCal09 calibration curve (Reimer et al. 2009).

\begin{tabular}{|c|c|c|c|c|c|c|c|c|c|c|c|}
\hline Lab nr & Material & $\begin{array}{l}\text { Position } \\
\text { on } \\
\text { gour-C } \\
\text { (cm/top) }\end{array}$ & $\begin{array}{l}\text { Error } \\
(\mathrm{cm})\end{array}$ & $\begin{array}{l}\text { Wt. } \\
(\mathrm{mg})\end{array}$ & $\begin{array}{l}{ }^{14} \mathrm{C} \\
(\mathrm{pMC})\end{array}$ & $\begin{array}{l}\text { AMS } \\
\delta^{13} \mathrm{C} \\
(\% 0)\end{array}$ & $\begin{array}{l}\text { Conv. } \\
\text { age }(1 \sigma) \\
(\text { yr BP) }\end{array}$ & $\begin{array}{l}\text { Cal. } \\
\text { age } \\
(\text { yr BP) }\end{array}$ & $\begin{array}{l}\text { Age } \\
-2 \sigma\end{array}$ & $\begin{array}{l}\text { Age } \\
+2 \sigma\end{array}$ & $\begin{array}{l}\text { Mean } \\
2 \sigma \\
\text { error } \\
(y r)\end{array}$ \\
\hline GifA-09 457 & Charcoal & 3.7 & 0.2 & 0.55 & $44.78 \pm 0.46$ & -30.6 & $6454 \pm 80$ & 7369 & 7558 & 7180 & 189 \\
\hline GifA-09 458 & Charcoal & 9.2 & 0.2 & 1.09 & $44.73 \pm 0.19$ & -32 & $6464 \pm 35$ & 7365 & 7435 & 7294 & 71 \\
\hline GifA-09 455 & Charcoal & 16.3 & 0.2 & 1.5 & $44.48 \pm 0.19$ & -32.8 & $6508 \pm 35$ & 7405 & 7486 & 7324 & 81 \\
\hline GifA-09 456 & Charcoal & 19 & 0.2 & 1.54 & $43.76 \pm 0.27$ & -28 & $6639 \pm 50$ & 7510 & 7585 & 7435 & 75 \\
\hline SacA 16006 & Extracted OM & 2.65 & 0.85 & 0.4 & $41.82 \pm 0.21$ & -30.2 & $7003 \pm 40$ & 7837 & 7936 & 7737 & 100 \\
\hline SacA 16007 & Extracted OM & 9.5 & 0.5 & 0.57 & $38.49 \pm 0.19$ & -30.4 & $7670 \pm 40$ & 8471 & 8544 & 8398 & 73 \\
\hline SacA 16008 & Extracted OM & 13.15 & 0.55 & 0.46 & $41.81 \pm 0.2$ & -31.4 & $7005 \pm 40$ & 7838 & 7937 & 7739 & 99 \\
\hline SacA 16009 & Extracted OM & 19 & 0.5 & 0.35 & $42.03 \pm 0.19$ & -28.3 & $6963 \pm 35$ & 7809 & 7923 & 7695 & 114 \\
\hline
\end{tabular}

\section{RESULTS AND DISCUSSION}

We first present the ${ }^{14} \mathrm{C}$ results of the charcoals and OM found in gour-C. Through these results, ${ }^{14} \mathrm{C}$ age models can be presented for the carbonates of all gour samples. These results are compared with former ${ }^{14} \mathrm{C}$ ages obtained in Lascaux Cave and with the few U-Th results we have obtained.

\section{Charcoals and Organic Matter ${ }^{14} \mathrm{C}$ Results Found in Gour-C}

Microscopic observation of 2 charcoals show large vessels similar to deciduous trees like oak. This is coherent with the leaf imprints (Corylus and Quercus) from the same calcite formation at the entrance of the cave and with former charcoal analyses (Leroi-Gourhan and Allain 1979). These later samples have been attributed to the Boreal period (Leroi-Gourhan and Allain 1979:185).

The new charcoal ages are in stratigraphic order in the gour-C sample and range from $6454 \pm 80$ to $6639 \pm 50 \mathrm{yr}$ BP (Figure 6, Table 2). These ages are significantly younger than those previously published, which range from $7510 \pm 650$ to $9070 \pm 90 \mathrm{yr} \mathrm{BP}$ (Table 2; Figures 7 and 8). This difference might be due to the sampling made in different layers: whereas our charcoals all come from gour-C, which is the ultimate phase of the carbonate construction, information gathered from the literature suggests that former charcoals come from the layer beneath, especially if we consider the original publication of Glory (1964; Table 1). ${ }^{8}$ In such a case, this would mean that the duration during which the charcoals were produced is much longer and spread from $6454 \pm 80$ to $9070 \pm 90 \mathrm{yr}$ BP $(10,498$ 9918 to $7558-7180$ yr cal BP).

That the charcoal ${ }^{14} \mathrm{C}$ ages of gour-C are in stratigraphic order suggests they have been produced and emplaced continuously during the construction of the carbonate gour and that their transportation by the flow stream from the cave entrance to the Passage chamber was relatively regular. Alternatively, the stratigraphic order of only 4 samples could be purely coincidental.

\footnotetext{
${ }^{8}$ There are some minor discrepancies between Glory (1964) and Leroi-Gouhran and Evin (1979). For example, the GrN 1182 and GrN 1514 sample positions in the cave are reversed in both publications; we took into consideration the oldest one (Glory 1964). Also, the GrN 1182 age is $240 \mathrm{yr}$ older in the Leroi-Gouhran and Evin article, which can be explain by a Suess effect correction suggested by Glory (1964: CXV). However, why this 240 -yr correction was not applied to the other samples, such GrN 1514 and GrN 3184, is not clear; we chose to keep the original age value published in Glory (1964).
} 


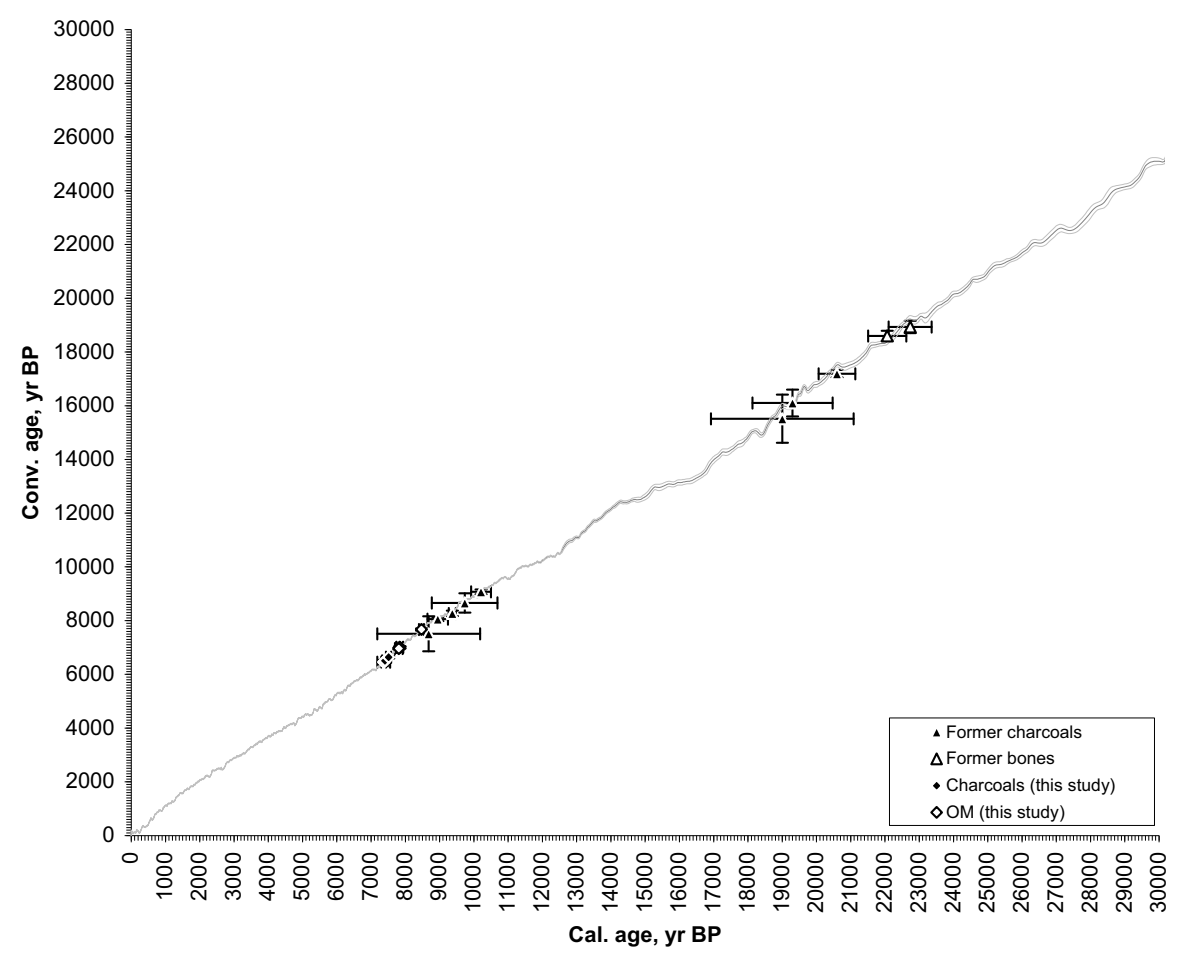

Figure $7{ }^{14} \mathrm{C}$ ages of organic remains of Lascaux Cave superimposed on the IntCal09 calibration curve (Reimer et al. 2009). See Table 1 for former ${ }^{14} \mathrm{C}$ analyses. Note that the new ${ }^{14} \mathrm{C}$ results made on charcoals and on OM are significantly younger than the former ${ }^{14} \mathrm{C}$ ages made on charcoals and on bones.

Extracted OM displays ages from $6963 \pm 35$ to $7670 \pm 35 \mathrm{yr} \mathrm{BP}$ (Table 2; Figure 7). They are older than the charcoals found in the same carbonate layers or very close to them ${ }^{9}$ (see $\mathrm{cm} /$ top values in Table 2; Figure 6). The charcoal average age is $6516 \pm 50 \mathrm{yr} \mathrm{BP}$, while the OM average age is $7160 \pm$ $40 \mathrm{yr}$ BP. OM ${ }^{14} \mathrm{C}$ ages are not in stratigraphical order, and samples taken at 9.5 and $13.15 \mathrm{~cm} / \mathrm{top}$, which are in fact in the same layer, do not show a similar age (Table 2; Figure 6).

The $\sim 500$-yr mean age difference between charcoals and OM could be due to the presence of old organic matter in the seepage water at the time of the gour deposition; this would explain not only the age difference, but also the disturbance in the chronology order. However, we cannot exclude also a possible mixing between old $\mathrm{OM}$ and modern $\mathrm{OM}$ due to the recent fungi contamination by Fusarium solani (Bastian et al. 2007, 2010), which we observed (felted gray material visible under binocular microscope) at the base of gour-C, especially on the surface of some charcoal particles (not dated). Consequently, we question if the age difference between charcoals and extracted OM is not due to a modern microbial/fungus contamination of the charcoals; if so, this contamination did not disturb the chronological order of the charcoal ${ }^{14} \mathrm{C}$ ages, but slightly offset them toward younger values. This hypothesis would also be consistent with our ${ }^{14} \mathrm{C}$ charcoal ages being younger than those of previous studies. However, because it is not possible to quantify these possible contaminations, the uncertainties they may bring to the dcp calculation could not be estimated.

\footnotetext{
${ }^{9}$ Charcoals and OM were not from exactly the same place because they were sampled at different times and also because the places where charcoals have been found trapped appear altered and porous with no clear stratigraphy. Due to the short time duration of gour-C growth, these stratigraphic differences are likely minor compared to other factors that have controlled the ${ }^{14} \mathrm{C}$ ages of the $\mathrm{OM}$ (e.g. variation of the old OM component in the seepage water).
} 


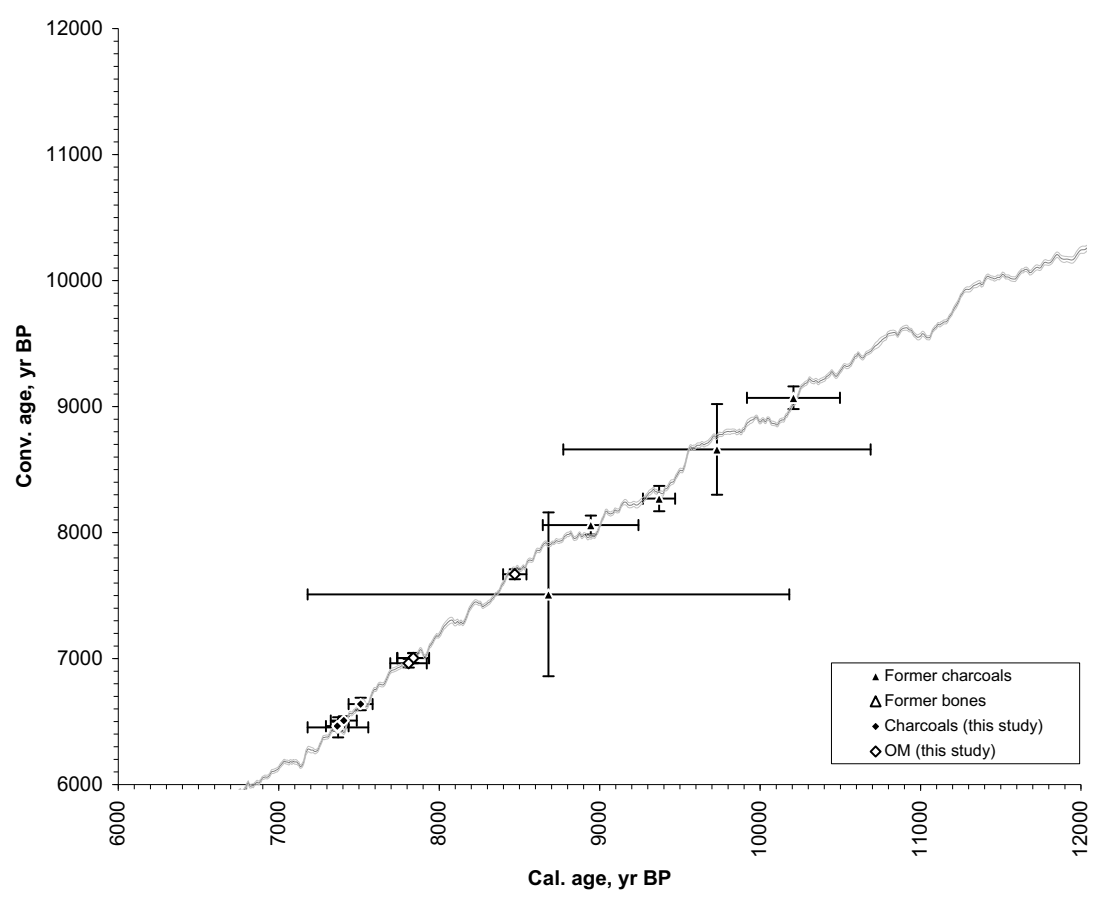

Figure $8{ }^{14} \mathrm{C}$ ages of organic matter (OM) of Lascaux Cave superimposed on the IntCal09 calibration curve (Reimer et al. 2009). Detail of Figure 7.

A next step in this study will be to make ${ }^{14} \mathrm{C}$ analyses on the different $\mathrm{OM}$ fractions after filtration. The filaments that are observed under the microscope, when isolated, might have a different ${ }^{14} \mathrm{C}$ age.

\section{U-Th Results}

Of the 5 carbonate pieces analyzed for U-Th dating, only 2 gave corrected ages with a $2 \sigma$ error of less than $1.5 \mathrm{ka}$ (Table 3 ). The large uncertainties obtained are due to the very high detrital or initial thorium contents of this material. While this can be corrected, it imparts very large uncertainties in this case (Hellstrom 2006). Fortunately, the best results are obtained at the top and base of the sample, allowing constraint of the gour-C growth to between $8092 \pm 1047 \mathrm{yr} / 2000(20 \mathrm{~cm} / \mathrm{top})$ and $7691 \pm 1392 \mathrm{yr} / 2000(1.5 \mathrm{~cm} /$ top $)$ (Table 3). Note that the charcoal and the $\mathrm{OM}{ }^{14} \mathrm{C}$ calibrated ages are both within the U-Th error ranges and that the ${ }^{14} \mathrm{C} \mathrm{OM}$ ages are, on average, closer to the U-Th ages (Figure 9; Table 2). ${ }^{10}$

\section{Gour Carbonate Age Model and Duration of Lascaux Gour Growth}

We made 3 series of carbonate ${ }^{14} \mathrm{C}$ analyses (Table 4):

1. The first was obtained on a vertical profile of the gour-C sample: $9{ }^{14} \mathrm{C}$ analyses at the locations of the U-Th and extracted OM samples (Figure 6);

2. The second was obtained on a lateral profile of gour- $\mathrm{C}$, in a place where the stratigraphy is clearer and perpendicular to it: $8{ }^{14} \mathrm{C}$ analyses (Figure 6);

3. The third was of the other gour samples: $3{ }^{14} \mathrm{C}$ analyses on gour- $\mathrm{A}$ and $4{ }^{14} \mathrm{C}$ analyses on gour$\mathrm{B}$; all analyses cover the top, middle, and base of the gour samples.

${ }^{10}$ Some $50 \mathrm{yr}$ were added to the ${ }^{14} \mathrm{C}$ cal. age BP in order to compare with the U-Th ages, which are in $\mathrm{yr} / 2000$. 
Table 3 Uranium-series age results of gour-C sample measured March 2009.

\begin{tabular}{lllllllllll}
\hline $\begin{array}{l}\text { Lab nr } \\
\text { (UMA-) }\end{array}$ & $\begin{array}{l}\text { Sample } \\
\text { name }\end{array}$ & cm/top & $\begin{array}{l}\text { Mass } \\
(\mathrm{g})\end{array}$ & $\begin{array}{l}\mathrm{U} \\
\left(\mathrm{ng} \mathrm{g}^{-1}\right)\end{array}$ & $\begin{array}{l}{ }^{230} \mathrm{Th} / \\
{ }^{238} \mathrm{U}^{\mathrm{a}}\end{array}$ & $\begin{array}{l}{ }^{234} \mathrm{U} / \\
{ }^{238} \mathrm{U}^{\mathrm{a}}\end{array}$ & $\begin{array}{l}{ }^{232} \mathrm{Th} / \\
{ }^{238} \mathrm{U}\end{array}$ & $\begin{array}{l}{ }^{230} \mathrm{Th} / \\
{ }^{232} \mathrm{Th}\end{array}$ & $\begin{array}{l}\text { Age } \\
(\mathrm{ka})\end{array}$ & $\begin{array}{l}{ }^{234} \mathrm{U} / \\
{ }^{238} \mathrm{U}^{\mathrm{c}}\end{array}$ \\
\hline 02622 & Lasc C & $1.50(0.3)$ & 0.0132 & 69 & 0.119 & 1.165 & 0.0642 & 1.8 & 7.7 & 1.169 \\
& $\mathrm{U}-\mathrm{Th}-1.5$ & & & & $(0.6)$ & $(0.8)$ & $(0.07)$ & & $(1.4)$ & $(0.8)$ \\
02623 & Lasc C & $8.50(0.3)$ & 0.0149 & 56 & 0.174 & 1.126 & 0.1097 & 1.6 & 11.2 & 1.130 \\
& U-Th-8.5 & & & & $(0.8)$ & $(0.8)$ & $(0.16)$ & & $(2.4)$ & $(0.6)$ \\
02624 & Lasc C & $12.30(0.3)$ & 0.0091 & 61 & 0.227 & 1.132 & 0.1977 & 1.1 & 11.2 & 1.136 \\
& U-Th-12.3 & & & & $(0.9)$ & $(1.0)$ & $(0.34)$ & & $(4.4)$ & $(1.1)$ \\
02625 & Lasc C & $17.80(0.5)$ & 0.0292 & 82 & 0.332 & 1.141 & 0.4598 & 0.7 & 4.3 & 1.143 \\
& U-Th-17.8 & & & & $(0.8)$ & $(0.5)$ & $(0.79)$ & & $(11.9)$ & $(0.7)$ \\
02626 & Lasc C & $20.00(0.5)$ & 0.0172 & 81 & 0.125 & 1.296 & 0.0524 & 2.4 & 8.1 & 1.303 \\
& U-Th-20 & & & & $(0.4)$ & $(0.7)$ & $(0.968)$ & & $(5.6)$ & $(0.8)$ \\
02587 & Lasc C & $20.00(0.5)$ & 0.0417 & 71 & 0.119 & 1.244 & 0.0494 & 2.4 & 8.1 & 1.249 \\
& U-Th-20bis & & & & $(0.6)$ & $(0.7)$ & $(0.16)$ & & $(1.0)$ & $(0.7)$ \\
\hline
\end{tabular}

${ }^{a}$ Activity ratios determined after Hellstrom (2003) using the decay constants of Cheng et al. (2000).

${ }^{\mathrm{b}}$ Age in kyr before present corrected for initial ${ }^{230} \mathrm{Th}$ using Equation 1 of Hellstrom (2006) and ${ }^{230} \mathrm{Th} /{ }^{232} \mathrm{Th}$ of $0.65 \pm 0.20$.

${ }^{234} \mathrm{U} / 238 \mathrm{U}$ at time of sample formation.

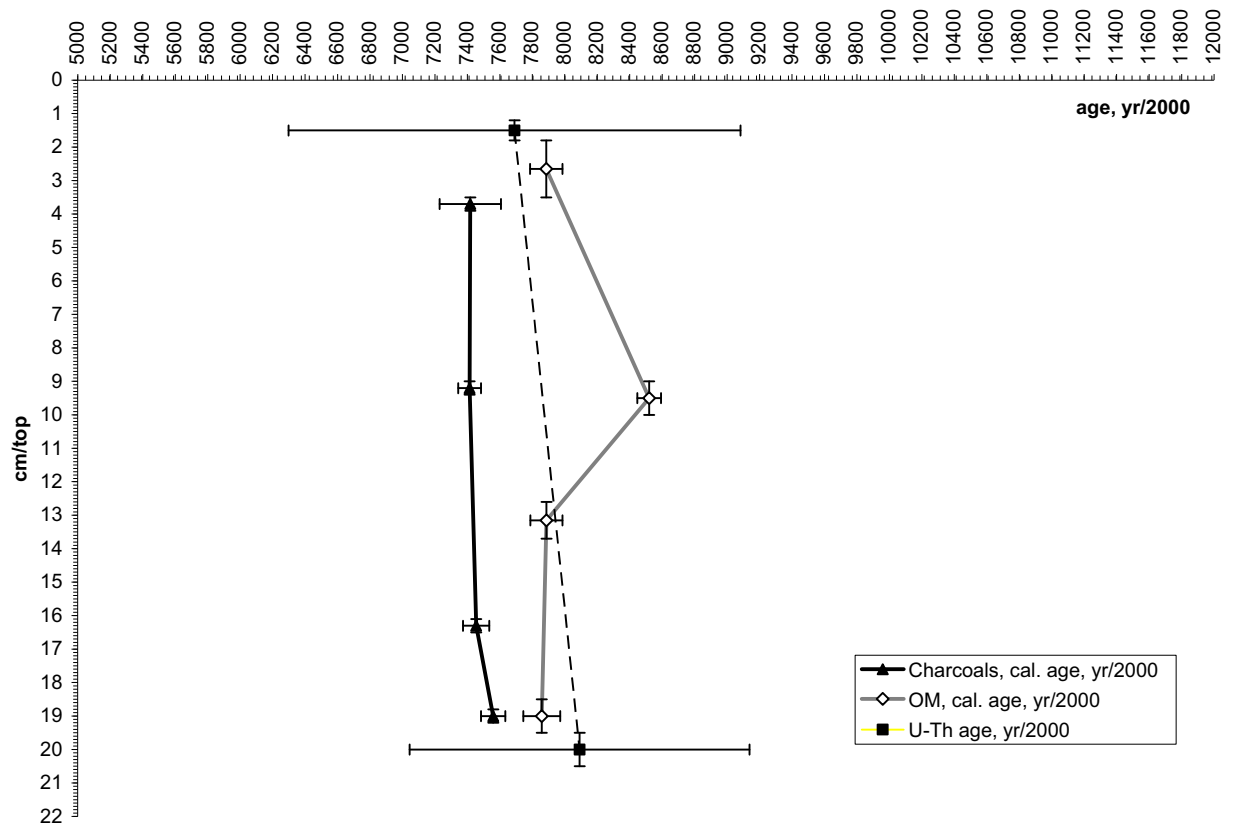

Figure 9 Gour-C vertical profile of the ${ }^{14} \mathrm{C}$ age made on the charcoals and the extracted $\mathrm{OM}$, compared with UTh ages and their $2 \sigma$ error limits. Errors bars are at $2 \sigma$. For convenience, we have put a central value for the ${ }^{14} \mathrm{C}$ ages, which is not exactly the maximum of probability.

In order to estimate an age by using ${ }^{14} \mathrm{C}$ activity measurements made on carbonate, it is necessary to first take into account the dead carbon proportion (dcp) or reservoir effect, which is the portion of free ${ }^{14} \mathrm{C}$ carbon injected in the seepage water, mainly coming from the limestone dissolution (Genty et al. 1999). In speleothem studies, the dep calculation is usually done by using the U-Th age as a true age (see Methods section for details), which cannot be done here without leading to very large age errors on the dep due to the large U-Th uncertainties: $\mathrm{dcp}_{\mathrm{U}-\mathrm{Th}}=13.9 \pm 15 \%$ (Table 4). Consequently, we have also used the charcoals and the $\mathrm{OM}{ }^{14} \mathrm{C}$ ages as "true" ages for the dcp calculations 
of the carbonate samples (Table 4). As explained above, charcoals and carbonate AMS measurements do not always coincide perfectly on the gour-C vertical section; however, this has likely a low influence on the dcp calculation because the charcoal ages show small variations and their position difference compared with the carbonate ones will lead to very small age differences.

Dead carbon proportion (dcp) values vary from $6.1 \%$ to $23.9 \%$ and average values, depending on the method used, vary from $10.7 \%$ to $20.5 \%$ (Table 4 ). These results are in agreement with previous dcp calculations made on Holocene speleothems, some of them being from the same area (within 50 $\mathrm{km}$; Genty et al. 2001). Because the charcoal calibrated ages are the youngest ones (compared with U-Th and OM analyses), the dcp found with them is the highest (20.5 $\pm 1.9 \%$; Table 4). The dcp found with U-Th (with carbonate at a same level) and OM (with carbonate at a different level) shows the same value of $13.9 \%$, however with large uncertainties for the U-Th calculations (Table 4). Finally, the lowest average dep is found with OM and carbonate from the same level $(10.7 \pm 1.8 \%)$.

The $13.9 \%$ dcp found with $\mathrm{OM}$ and the closest carbonate sample is likely slightly overestimated because the OM comes from a slightly lower (older) level (Figure 6). Thus, in order to correct the carbonate ${ }^{14} \mathrm{C}$ activity, we first chose the dcp that was calculated with material from the same level and where the true ages have the best error, which is for the $\mathrm{OM} /$ carbonate $(\mathrm{dcp}=10.7 \%)$. This choice is supported by the fact that this $10.7 \pm 1.8 \% \mathrm{dcp}$ value is the closest to the ones found in speleothems from the Villars and La Faurie caves, which are in the same area (9 to $9.4 \pm 1.5 \%$; Genty et al. 2001). Note that calculations made with the $13.9 \%$ dcp do not significantly change the corrected ages with respect to their error bars (Table 5). We also made carbonate age calculations with the $20.5 \pm 1.9 \% \mathrm{dcp}$ found with the charcoals as the resulting age uncertainties on the latter are small; this assumes that the charcoals are contemporaneous of the carbonate deposit (Table 5).

Carbonate ages made on all the gour samples (gour-A, -B, and -C), corrected with $10.7 \%$ dcp and calibrated with the IntCal09 calibration curve, range from 9530 cal yr BP (base of gour-B, lower age limit at $-2 \sigma$ ) to 7290 cal yr BP (top of gour-C, lateral profile, upper age limit at $+2 \sigma$ ) (Figure 10a,b; Table 5). If we consider a dcp of $20.5 \%$, the calibrated ages of the carbonate deposit range from 8518 cal yr BP (base of gour-B, lower age limit at $-2 \sigma$ ) to $6285 \mathrm{cal} \mathrm{yr} \mathrm{BP} \mathrm{(top} \mathrm{of} \mathrm{gour-C,} \mathrm{lateral} \mathrm{profile,}$ upper age limit at $+2 \sigma$ ) (Table 5). The average difference between ages estimated with $10.7 \% \mathrm{dcp}$ and the $20.5 \%$ dcp is $\sim 940 \mathrm{yr}$.

Even if there are overlapping ages between the 3 different gours, these results show that the oldest one is gour-B and the youngest one is gour-C. The entire set of gour samples grew in a relatively narrow range of time ( $\sim 1340 \mathrm{yr}$; Figure 11). For gour-C, where it was possible to make a continuous dating profile along the growth layers (lateral profile), the growth duration is less than $\sim 500 \mathrm{yr}$ (from $\sim 8213$ to $\sim 7778 \mathrm{cal} \mathrm{yr} / 2000$; Table 5). Interestingly, the U-Th ages of the top and the base of gour$\mathrm{C}$ are between the carbonate ages found with a dcp of $10.7 \%$ and $20.5 \%$, respectively, giving more confidence in the dating methods despite their relatively large errors (Figure 10a; Table 5).

\section{Possible Causes of Lascaux Gour Development}

The beginning of the Holocene is known to have been humid in many places under influence; the land/sea temperature contrast due to increased insolation produced more intense precipitation (Huang et al. 2008). For example, a pollen sediment record from N China show a marked humid period between 9 and $7 \mathrm{ka} \mathrm{BP}$ (Cui et al. 2009); the Dongge Cave speleothem from S China also displays an intensification of the monsoon between $\sim 7$ and $\sim 9$ ka BP (Dykoski et al. 2005). Closer to Europe, lakes and wetlands developed in the present-day Sahara at $\sim 8.5 \mathrm{ka}$ BP demonstrate the role of change of the ITCZ position with time (Watrin et al. 2009). Several other records found in Africa and the Middle East have recorded the Holocene Humid Period (HHP) and its consequences on the 


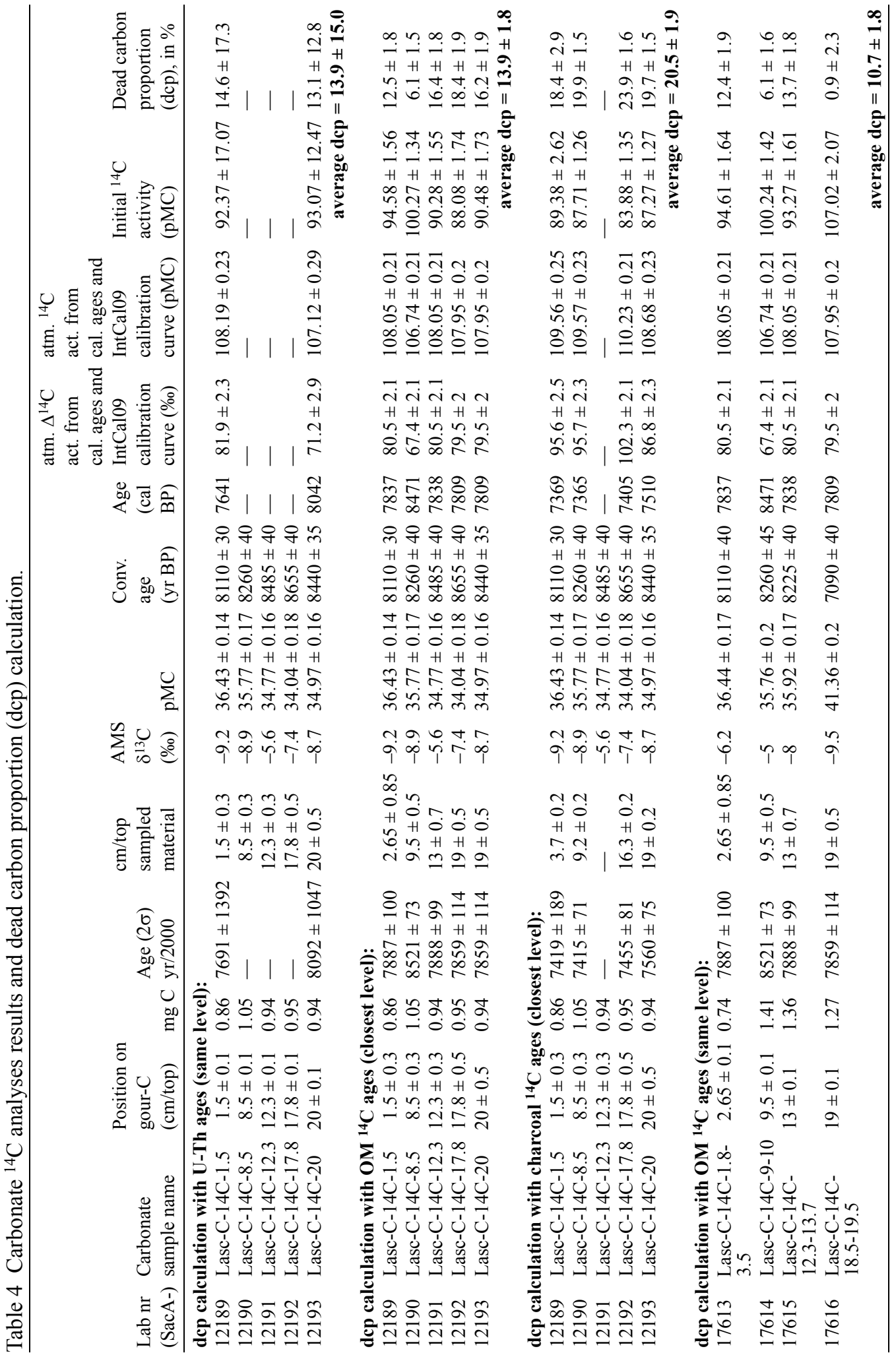




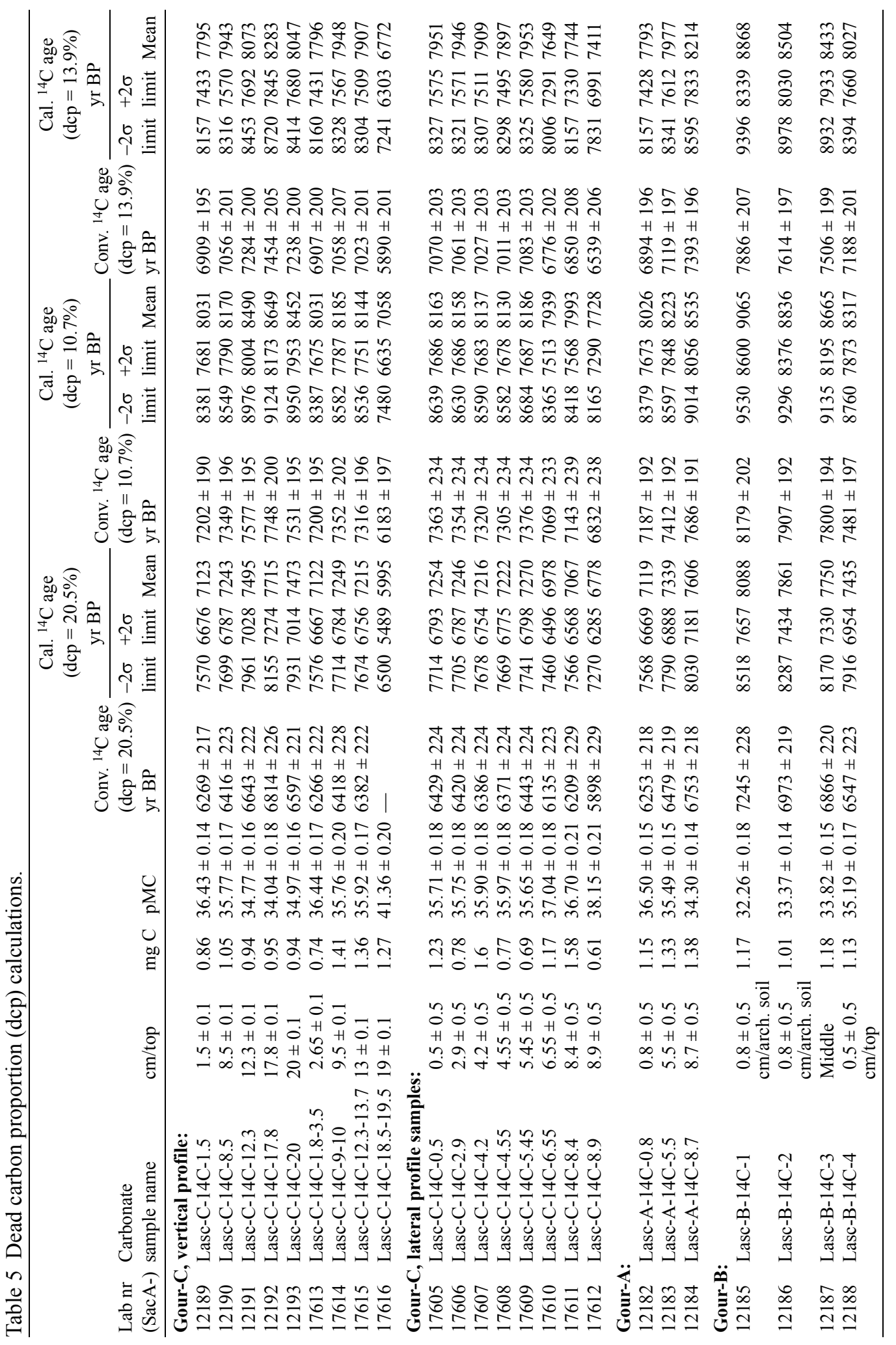




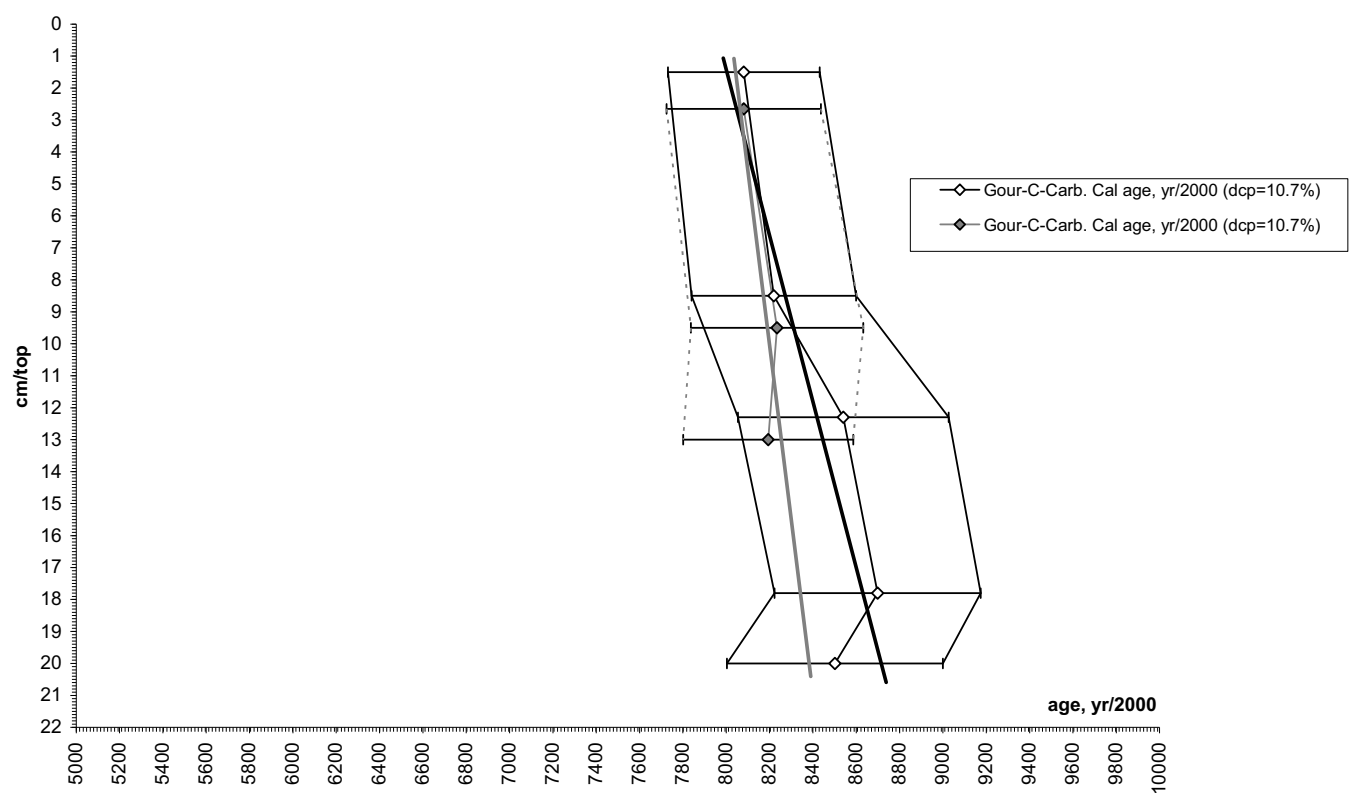

Figure 10 a) Carbonate ${ }^{14} \mathrm{C}$ ages of the vertical profile of gour-C. Both calculations using $\mathrm{dcp}=10.5 \%$ and $20.7 \%$ are reported; for convenience, we have put the mean ${ }^{14} \mathrm{C}$ cal age and the $2 \sigma$ limits. Note that the growth rate of gour-C was fast and that the U-Th ages (gray squares) are between the ${ }^{14} \mathrm{C}$ cal ages estimated with both $\operatorname{dcp}(10.7 \%$ and $20.5 \%)$.

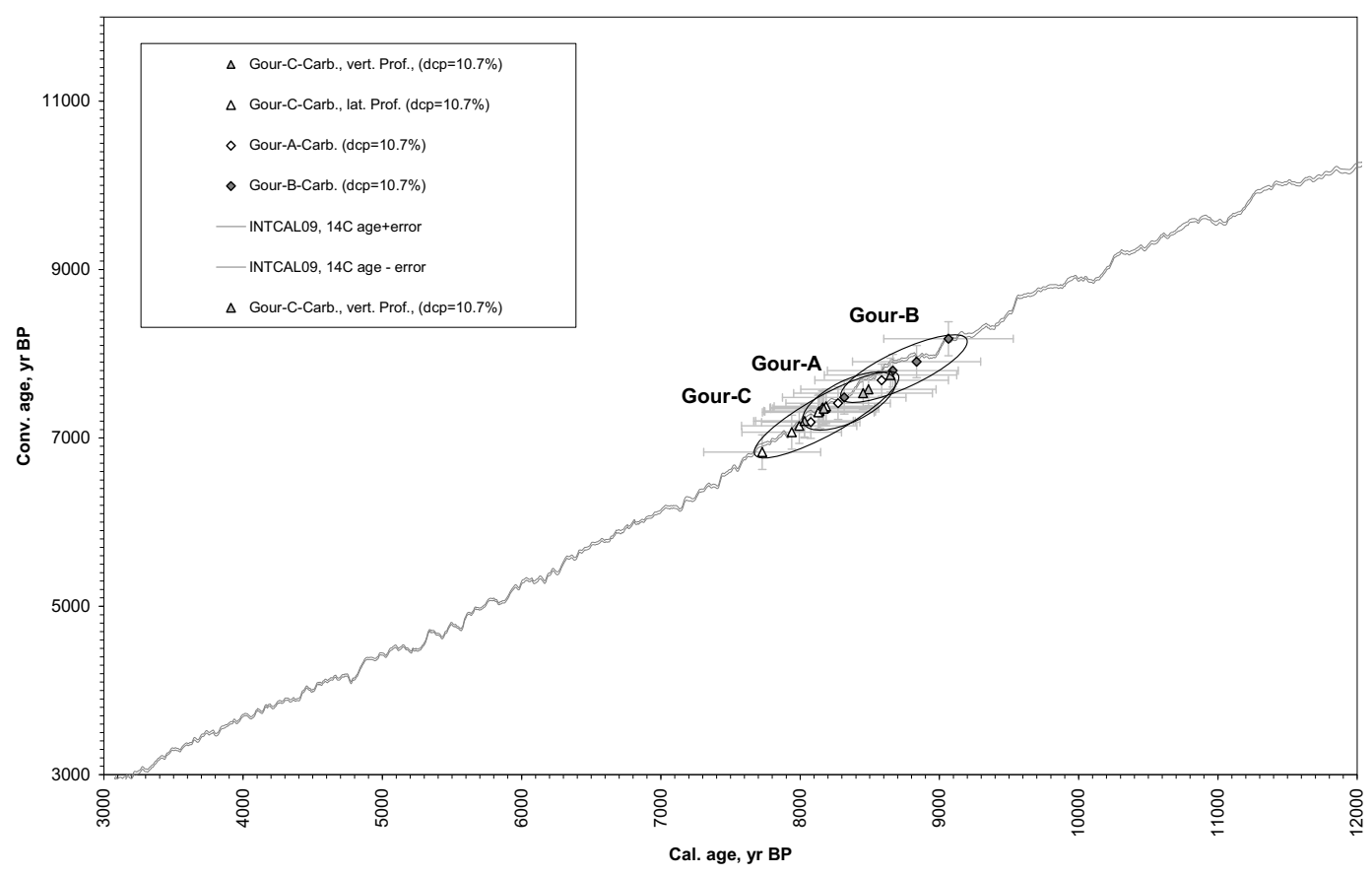

Figure 11 Carbonate ${ }^{14} \mathrm{C}$ ages of the Lascaux gours with a dead carbon proportion (dcp) of $10.7 \%$. Note that the oldest age is from the base of gour-B and that the youngest one is from the top of gour-C. 
vegetation at $\sim 9$ and 8 ka BP (Fleitmann et al. 2003; Lezine et al. 2007; Ivory and Lezine 2009). Southern Hemisphere paleoclimatic archives also recorded a humid period at the beginning of the Holocene like the one found in Namibia between 8.7 and 7.5 cal ka BP (Chase et al. 2010).

Sapropel events that are linked with humid periods around the eastern Mediterranean Sea have been dated by speleothems found in Soreq Cave, Israel (Bar-Matthews et al. 2000). The youngest one, called the $\mathrm{S} 1$ event, occurred between $\sim 8.5$ and $\sim 7 \mathrm{cal} \mathrm{ka} \mathrm{BP}$ and coincides with the Lascaux gour development. Closer to Lascaux Cave, the Corchia Cave in N Italy recorded also a well-marked isotopic anomaly between 8.9 and $7.3 \mathrm{ka}$ cal BP that was interpreted as a humid period (Zanchetta et al. 2007) (Figure 12). This raises the question of the influence of these Mediterranean humid events on higher latitudes and western parts of Europe. If the hypothesis of large freshwater input in the eastern Mediterranean Sea (MS) through more intense rainfalls and/or more fresh influxes from the Nile River through the Ethiopian Highlands seems reasonable, these results suggest that the influence of these humid periods on the western side of the MS was also significant. Southwest France is not directly influenced by the African Monsoon as can be the eastern part of the MS, but more likely by the Atlantic air circulation changes due to changes in air pressure patterns (i.e. North Atlantic Oscillation). There is a possible influence of the Mediterranean depression pathways too, but little is known about past changes of both influences in this area.

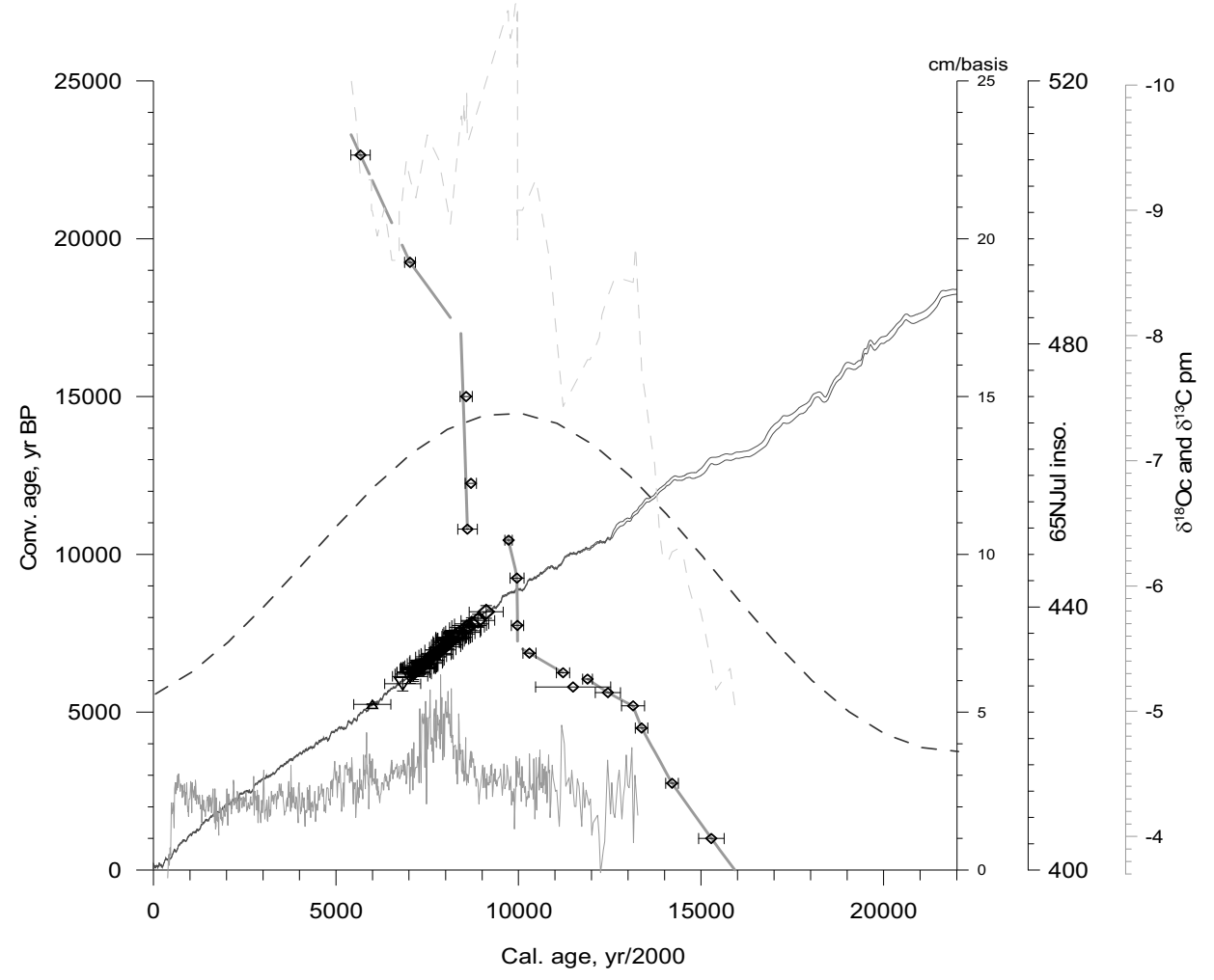

Figure 12 Comparison between Lascaux gour periods of growth (black dots) and 1) the Vil-stm1 growth rate (thick gray line with dated diamond points and $2 \sigma$ errors) and Vil-stm $11 \delta^{13} \mathrm{C}$ (light gray dotted line) (Genty et al. 2006); 2) Chorchia Cave CC26 stalagmite $\delta^{18} \mathrm{O}$ (thin light gray line; Zanchetta et al. 2007); and 3) the July $65^{\circ} \mathrm{N}$ insolation (dashed line). The IntCal09 calibration curve is superimposed (thin dark gray line). Note that the gour development coincides with the fastest growth rate of Vil-stm11; the hiatus that occurred between 9.7 and $8.6 \mathrm{ka}$ is likely due to a cave flooding (as the stable isotopes did not show a cooler climate around this period). 
Well-dated paleoclimatic records in SW France are rare, but among them, one Villars Cave stalagmite (Vil-stm11), $50 \mathrm{~km}$ northwest of Lascaux, displays a very high growth rate between 8.6 and 8.4 $\mathrm{ka}( \pm 0.3 \mathrm{ka})$, contemporaneous to the Lascaux gour growth (Genty et al. 2006: Figure 12). It is interesting to note that the $\delta^{13} \mathrm{C}$ signal of the same Vil-stm11 stalagmite displays a depleted peak (interpreted as a warm/humid period) that started just before the gour development but continued thereafter, coinciding with the gour ages and partly with the Chorchia Cave $\delta^{18} \mathrm{O}$ anomaly (Figure 12).

The $65^{\circ} \mathrm{N}$ insolation that drives the Northern Hemisphere ice sheet cover displays a maximum at $\sim 10 \mathrm{ka}$, just before the beginning of the Lascaux gour development (Figure 12). By changing land/ sea temperature contrasts, it enhanced the global hydrological activity, too, especially the monsoon and the ITCZ position at lower latitudes, with possible consequences at higher latitudes like those in western Europe.

Besides a climatic cause, the Lascaux gour growth may have been triggered by a geomorphological event like the entrance collapse suggested by the $\sim 1-\mathrm{m}$-thick limestone layer found just bellow the calcite layer that constitutes the gours (éboulis in Figure 2). This collapse occurred after the human occupation marked by the archaeological layer (couche archéologique in Figure 12) and consists of large boulders that come from the ancient cave vault (Leroi-Gourhan and Allain 1979). It certainly favored the drainage of seepage water toward the inside of the cave. The cause of this collapse is unknown, but more humid conditions might also have helped in the destruction of the relatively thin cave ceiling there.

\section{CONCLUSION}

Through the comparison of radiometric datings made on charcoals, organic matter, and carbonate we give time constraints to the Lascaux Cave gour development. First, the charcoals trapped in gour-C from the Passage chamber are between 7585 and $7180 \mathrm{yr}$ cal BP $(2 \sigma)$, which is significantly younger than the former ${ }^{14} \mathrm{C}$ analyses made in the 1960s and 1970s for still unknown reasons. The organic matter $(\mathrm{OM})$ extracted from the same gour-C sample is slightly older than the trapped charcoals, 8544 to $7695 \mathrm{yr}$ cal BP $(2 \sigma)$, possibly due to an old carbon fraction component when trapped during calcite growth. Considering either the charcoals or the OM ages, we estimated the dead carbon proportion (dcp) at $20.5 \%$ and $10.7 \%$, respectively. Using these values and the IntCal09 calibration curve, we estimated the ${ }^{14} \mathrm{C}$ age of the gour calcite. Results show that the Lascaux Cave gours developed between 9530 and $6635 \mathrm{yr}$ cal BP (for dcp $=10.7 \pm 1.8 \% ; 2 \sigma$ ) or between 8518 and 5489 yr cal BP (for dcp $=20.5 \pm 1.9 \% ; 2 \sigma$ ), which is coherent with the few U-Th ages obtained, despite their high uncertainties. All of these results demonstrate that the Lascaux gour had not been active (no significant water stream entered the cave) for several millennia when the cave was discovered in 1940 and its potential role in the painting conservation, by the constitution of freshwater dams in the cave that could have regulated the temperature and the humidity, is less likely minimal. The main cause of the Lascaux gour development is uncertain; however, its coincidence with already known humid periods such as the Sapropel 1 in the Eastern Mediterranean Basin question the connection between the eastern and western parts of the Mediterranean region. Besides a humid period, the collapse of the cave entrance likely played an important role in the Lascaux gour construction.

\section{ACKNOWLEDGMENTS}

First, we thank J M Geneste, director of the Centre National de Préhistoire (Périgueux), who was the Lascaux Cave curator when this study started and who initiated it. We are grateful to the Lascaux Cave supervisors, Sandrine van Solinge and Bruno Desplat, for the organization and their help during the Lascaux Cave visits. We also thank J-P Cazet for the OM extraction, Ph Orengo for sampling 
help, and B and G Delluc for their precious help in the bibliography and their helpful discussions, F Mansouri for stable isotope analyses, S Thiébault for the charcoals observation, and E Robin and P Weil for SEM images d to h. Finally, we thank U von Grafentein for assistance with English proofreading. All ${ }^{14} \mathrm{C}$ measurements were made by the LMC 14, ARTEMIS AMS, UMS 2572, CEA Saclay. This study was partly funded by the CEA and the CNRS (INSU).

\section{REFERENCES}

Aujoulat N. 2004. Lascaux. Le geste, l'espace et le temps. Paris: Seuil.

Arnold JR, Libby WF. 1951. Radiocarbon dates. Science 113(2927):111-20.

Bar-Matthews M, Ayalon A, Kaufman A. 2000. Timing and hydrological conditions of Sapropel events in the eastern Mediterranean, as evident from speleothems, Soreq cave, Israel. Chemical Geology 169(1-2):14556.

Bastian F, Alabouvette C. 2009. Lights and shadows on the conservation of a rock art cave: the case of Lascaux Cave. International Journal of Speleology 38(12):55-60.

Bastian F, Orial G, Francois A, Alabouvette C. 2007. The Lascaux cave. A complex ecosystem where bacteria and fungus interact. Biofutur 283:28-31.

Bastian F, Alabouvette C, Saiz-Jimenez C. 2009. The impact of arthropods on fungal community structure in Lascaux Cave. Journal of Applied Microbiology 106(5):1456-62.

Bastian F, Jurado V, Novakova A, Alabouvette C, SaizJimenez C. 2010. The microbiology of Lascaux Cave. Microbiology 156(3):644-52.

Berrouet F. 2009. Les altérations d'origine biologique dans l'art pariétal: exemple des relations structurales et conceptuelles entre le mondmilch et les représentations paléolithiques. Bordeaux: University of Bordeaux 1. 280 p.

Billy C, Blanc P. 1977. Application du MEB à la cristallogenèse bactérienne d'aragonite et de calcite. Travaux du Laboratoire de Micropaléotologie 7:171-86.

Billy C, Chalvignac MA. 1976. Role of biological factors in calcification of caves of Lascaux and Font-DeGaume. Comptes Rendus Hebdomadaires des Seances de L'Academie des Sciences Serie D 283(2):207-9.

Borsato A, Frisia S, Jones B, Van der Borg K. 2000. Calcite moonmilk: crystal morphology and environment of formation in caves in the Italian Alps. Journal of Sedimentary Research 70(5):1171-82.

Bronk Ramsey C. 1995. Radiocarbon calibration and analysis of stratigraphy: the OxCal program. Radiocarbon 37(2):425-30.

Bronk Ramsey C. 2001. Development of the radiocarbon calibration program. Radiocarbon 43(2A):355-63.

Casanova J. 1981. Morphologie et biolithogénèse des barrages de travertins. Mémoire de l'Association Française de Karstologie 3:45-54.

Chase BM, Meadows ME, Carr AS, Reimer PJ. 2010. Evidence for progressive Holocene aridification in southern Africa recorded in Namibian hyrax middens: implications for African Monsoon dynamics and the "African Humid Period." Quaternary Research 74(1): $36-45$.

Cheng H, Edwards RL, Hoff J, Gallup CD, Richards DA, Asmerom Y. 2000. The half-lives of uranium-234 and thorium-230. Chemical Geology 169:17-33.

Cui JX, Zhou SZ, Chang H. 2009. The Holocene warmhumid phases in the North China Plain as recorded by multi-proxy records. Chinese Journal of Oceanology and Limnology 27(1):147-61.

Delibrias G, Guillier MT, Labeyrie J. 1964. Saclay natural radiocarbon measurements I. Radiocarbon 6:23350.

Delluc B, Delluc G. 2003. Lascaux retrouvé. Périgueux: Pilote 24. 364 p.

Delluc B, Delluc G. 2008. Dictionnaire de Lascaux. Paris: Editions Sud-Ouest. 349 p.

Dykoski CA, Edwards RL, Cheng H, Yuan D, Cai Y, Zhang M, Lin Y, Qing J, An ZS, Revenaugh J. 2005. A high-resolution, absolute-dated Holocene and deglacial Asian monsoon record from Dongge Cave, China. Earth and Planetary Science Letters 233(1-2): 71-86.

Fleitmann D, Burns SJ, Neff U, Mangini A, Matter A. 2003. Changing moisture sources over the last 330,000 years in Northern Oman from fluid-inclusion evidence in speleothems. Quaternary Research 60(2): 223-32.

Fletcher WJ, Goni MFS, Peyron O, Dormoy I. 2010. Abrupt climate changes of the last deglaciation detected in a Western Mediterranean forest record. Climate of the Past 6(2):245-64.

Frisia S, Borsato A, Fairchild IJ, McDermott F. 2000. Calcite fabrics, growth mechanisms, and environments of formation in speleothems from the Italian Alps and southwestern Ireland. Journal of Sedimentary Research 70(5):1183-96.

Frisia S, Borsato A, Spotl C, Villa IM, Cucchi F. 2005. Climate variability in the SE Alps of Italy over the past 17000 years reconstructed from a stalagmite record. Boreas 34(4):445-55.

Genty D, Quinif Y. 1996. Annually laminated sequences in the internal structure of some Belgian stalagmites importance for paleoclimatology. Journal of Sedimentary Research 66(1):275-88.

Genty D, Massault M, Gilmour M, Baker A, Verheyden S, Kepens E. 1999. Calculation of past dead carbon proportion and variability by the comparison of AMS 
${ }^{14} \mathrm{C}$ and TIMS U/Th ages on two Holocene stalagmites. Radiocarbon 41(3):251-70.

Genty D, Baker A, Massault M, Proctor C, Gilmour M, Pons-Branchu E, Hamelin B. 2001. Dead carbon in stalagmites: carbonate bedrock paleodissolution vs. ageing of soil organic matter. Implication for ${ }^{13} \mathrm{C}$ variation in speleothems. Geochimica et Cosmochimica Acta 65(20):3443-57.

Genty D, Blamart D, Ghaleb B, Plagnes V, Causse C, Bakalowicz M, Zouari K, Chkir N, Hellstrom J, Wainer K, Bourges F. 2006. Timing and dynamics of the last deglaciation from European and North African $\delta^{13} \mathrm{C}$ stalagmite profiles - comparison with Chinese and South Hemisphere stalagmites. Quaternary Science Reviews 25(17-18):2118-42.

Glory A. 1964. Datation des peintures de Lascaux par le radio-carbone. Bulletin de la Société Préhistorique Française 5:CXIV-CXVII.

Glory A, Delluc B, Delluc G. 2008. Les recherches à Lascaux (1952-1963). Gallia Préhistoire XXXIX:201.

Guyon PM. 1980. La conservation des peintures pariétales. Contribution aux travaux de la Commission scientifique de Lascaux. Revue de Synthèse III(97-98):115-44.

Hellstrom J. 2003. Rapid and accurate U/Th dating using parallel ion-counting multi-collector ICP-MS. Journal of Analytical Atomic Spectrometry 18(11):1346-51.

Hellstrom J. 2006. U-Th dating of speleothems with high initial ${ }^{230} \mathrm{Th}$ using stratigraphical constraint. Quaternary Geochronology 1(4):289-95.

Huang JB, Wang SW, Wen XY, Yang B. 2008. Progress in studies of the climate of humid period and the impacts of changing precession in early-mid Holocene. Progress in Natural Science 18(12):1459-64.

Ivory SJ, Lezine AM. 2009. Climate and environmental change at the end of the Holocene Humid Period: a pollen record off Pakistan. Comptes Rendus Geoscience 341(8-9):760-9.

Lacanette D, Vincent S, Sarthou A, Malaurent P, Caltagirone JP. 2009. An Eulerian/Lagrangian method for the numerical simulation of incompressible convection flows interacting with complex obstacles: application to the natural convection in the Lascaux cave. International Journal of Heat and Mass Transfer 52(11-12): 2528-42.

Leroi-Gourhan A, Allain J. 1979. Lascaux Inconnu. XIIe supplément à Gallia Préhistoire. Paris: CNRS. 379 p.

Leroi-Gourhan A, Evin J. 1979. Les datations de Lascaux. In: Lascaux Inconnu. Paris: CNRS. p 81-4.
Lezine AM, Tiercelin JJ, Robert C, Saliege JF, Cleuziou S, Inizan ML, Braemer F. 2007. Centennial to millennial-scale variability of the Indian monsoon during the early Holocene from a sediment, pollen and isotope record from the desert of Yemen. Palaeogeography, Palaeoclimatology, Palaeoecology 243(3-4):235-49.

Libby WF. 1952. Radiocarbon Dating. Chicago: University of Chicago Press.

Luetscher M, Jeannin PY. 2004. Temperature distribution in karst systems: the role of air and water fluxes. Terra Nova 16(6):344-50.

Magny M, Bégeot C. 2004. Hydrological changes in the European midlatitudes associated with freshwater outbursts from Lake Agassiz during the Younger Dryas event and the early Holocene. Quaternary Research 61(2):181-92.

Mook WG, van der Plicht J. 1999. Reporting ${ }^{14} \mathrm{C}$ activities and concentrations. Radiocarbon 41(3):227-39.

Reimer PJ, Baillie MGL, Bard E, Bayliss A, Beck JW, Blackwell PG, Bronk Ramsey C, Buck CE, Burr GS, Edwards RL, Friedrich M, Grootes PM, Guilderson TP, Hajdas I, Heaton TJ, Hogg AG, Hughen KA, Kaiser KF, Kromer B, McCormac FG, Manning SW, Reimer RW, Richards DA, Southon JR, Talamo S, Turney CSM, van der Plicht J, Weyhenmeyer CE. 2009. IntCal09 and Marine09 radiocarbon age calibration curves, $0-50,000$ years cal BP. Radiocarbon 51(4): 1111-50.

Renssen H, Isarin RFB, Jacob D, Podzun R, Vandenberghe J. 2001. Simulation of the Younger Dryas climate in Europe using a regional climate model nested in an AGCM: preliminary results. Global and Planetary Change 30(1-2):41-57.

Taine J, Lacona E, Petit JP. 2003. Transferts thermiques, introduction aux transferts d'énergie. Paris: Dunod.

Vogel JC, Waterbolk HT. 1963. Groningen radiocarbon dates IV. Radiocarbon 5:163-202.

Vouvé J. 1979. Etude géologique et genèse hydrokarstique. In: Lascaux Inconnu. Paris: CNRS. p 35-9.

Watrin J, Lezine AM, Hely C. 2009. Plant migration and plant communities at the time of the "green Sahara." Comptes Rendus Geoscience 341(8-9):656-70.

Zanchetta G, Drysdale RN, Hellstrom JC, Fallick AE, Isola I, Gagan MK, Pareschi MT. 2007. Enhanced rainfall in the Western Mediterranean during deposition of sapropel S1: stalagmite evidence from Corchia cave (Central Italy). Quaternary Science Reviews 26(3-4):279-86. 